\title{
Events in the Precambrian history of the Earth; challenges in discriminating their global significance
}

\author{
P.G. Eriksson ${ }^{\mathrm{a}^{*}}$, O. Catuneanu ${ }^{\mathrm{b}}$, D.R. Nelson ${ }^{\mathrm{c}}$, M.J. Rigby ${ }^{\mathrm{a}}$, P.C. \\ Bandopadhyay $^{\mathrm{d}}$ and W. Altermann ${ }^{\mathrm{a}}$ \\ ${ }^{a}$ Department of Geology, University of Pretoria, Pretoria 0002, South Africa \\ ${ }^{b}$ Department of Earth and Atmospheric Sciences, 1-26 Earth Sciences Building, University of \\ Alberta, Edmonton, Alberta T6G 2E3, Canada \\ ${ }^{c}$ Intierra Resource Intelligence, Level 1, 6 Thelma St., West Perth, Western Australia 6005 \\ ${ }^{d}$ Geological Survey of India, Bhu-Bijnan Bhavan, DK-6, Sector-II, Salt Lake, Kolkata 700091 , \\ India
}

\begin{abstract}
This paper discusses geological events with an approximately global preservational scale which can aid inter-cratonic correlations and contribute to postulates of supercontinents for a set of chosen Precambrian cratons. The chronological scale of such events is highly variable, and most event types detailed (supercontinent-, mantle plume-, orogenic-, chemostratigraphic-, glacial events and major unconformities) have durations concomitant with the large scale interaction of mantle thermal and plate tectonic processes that were largely responsible for their genesis, i.e. 10's to 100 's of millions of years. Geologically instantaneous events of global compass (e.g., impact or major eruptive events) provide important chronological markers for interpreting the longer term events. The same interplay of tectono-thermal geodynamic processes that drives the evolution of the Earth and the operation of its supercontinent cycles is also, ultimately, responsible for and of comparable duration to first- and second-order sequence stratigraphic cyclicity. This paper thus serves to introduce these concepts and discuss the problems in their application to specific Precambrian cratons, in relation to the aim of this special issue, of providing a set of accommodation curves for many of these ancient crustal terranes.
\end{abstract}

Keywords: Geological events; Geochronology; Supercontinents; Mantle plumes; Impacts; Orogenies; Chemochronological events; Glaciation; Unconformities; First- and second-order sequence stratigraphic cyclicity

\section{Introduction}

The term "event" is one that is used (and possibly abused also) to a relatively great degree within geology generally, and in Precambrian studies particularly. The definition of an "event" depends to a large extent on the resolution of data and the scale of observation. As approached within this paper, an event must be directly associated with identifiable products preserved within the rock record. Often, the term event is used to denote large scale geological occurrences of significant age ranges such as orogenies, large magmatic intrusions (encompassing also mantle plumes and superplumes, and globally significant and chronologically restricted assemblages thereof, superplume events; cf. terminology of Condie, 2004a and Ernst et al., 2004), supercontinental breakups, palaeoclimatic episodes (particularly glaciations), eustatic advances and retreats, biological extinction events, and periods of meteorite bombardment of the Earth. 
At an even larger scale of consideration, some workers go as far as identifying "superevents", temporal clusters of such large scale events, when the planet underwent a whole series of significant changes in geodynamics, ocean and atmosphere chemistry, palaeoclimate and biological evolution; as an example, Eriksson et al. (2004a; 2005a) discussed c. $2.7 \mathrm{Ga}$ and succeeding c. 2.2-1.8 Ga super-events, separated by global-scale relative tectonic quiescence (Fig. 1). All of these views of the concept of an "event" are at a large scale (at least cratonic if not continental, and some even of global or quasi-global compass), with durations encapsulating tens to even several hundred million years.

At the other end of the chronological scale, there are events such as a single catastrophic bolide impact (e.g., the K-T boundary), a violent volcanic eruption such as at Santorini in the eastern Mediterranean (c. 1628 B.C.; Manning 1999), Krakatau in Indonesia (26-27 ${ }^{\text {th }}$ August, 1883) or Mount St. Helens in the NW USA (18 ${ }^{\text {th }}$ May 1980), or a major earthquake and/or tsunami (such as the tragic events in the Indian ocean on $26^{\text {th }}$ December 2004). Such events may be seen as geologically instantaneous as they generally occur over periods of some hours or a few days.

As the theme of this special issue deals with possible global correlations for the Precambrian time period, particularly those of stratigraphic affinity and even more so those that can be related to first- and second-order sequence stratigraphy, any potentially useful "events" must have an essentially global spatial scale. Even if the event itself might not have been global in scale, the preserved products or proxies from that event must have that scale to be useful in correlations between the extant widely dispersed Precambrian cratons. A large geographic scale is thus implicit for events discussed in this paper and issue; in contrast, the temporal scale of potential events is highly variable, as outlined above. It is thus logical to attempt global correlations at larger scale first, at the rank of first- and second-order sequence stratigraphic cycles. Moreover, the maximum resolution of geochronological techniques (c. 1-10 Ma) does not allow confident identification and correlation of the smaller scale (i.e., higher frequency, or lower order) cycles (Catuneanu and Eriksson, 1999). For these reasons, this special issue will essentially restrict its discussions to first- and second-order cyclicity, which relate to the most important events, sequence boundaries and sequences in the Precambrian record.

Notwithstanding the consequent large-scale scope of this special issue, short-lived, essentially immediate geological events and their products, such as spherule beds or widespread ash deposits with unique geochemical signatures, are considered, as they provide extremely useful correlation points between the supracrustal successions of dispersed Precambrian cratons. They have the potential to provide critical time lines to aid correlation between Precambrian cratons within the resolution of first- and secondorder sequence stratigraphy. However, the preserved geological expressions of such time lines are relatively thin and difficult to locate within often deformed and metamorphosed Precambrian basin-fill successions. Palaeosols, often also difficult to identify and define, offer analogous challenges; in contrast, erosional hiatuses are simpler to identify, but depend on accurate geochronology to define their time constraints.

Defining what is meant by a global event, whether the term encompasses all events whose effects were global in scale or only those which were similar in intensity or scale around the world, is also problematic. As an example, a major bolide impact or largescale violent volcanic eruption will have enormous effects at scales from several tens of kilometres to that of approximately cratonic compass (with concomitant tsunamis 
potentially affecting areas hundreds of kilometres distant), allied to their indirect, longer term results such as clouds of fine atmospheric debris, which will almost certainly spread around the planet and result in global-scale climatic effects. In contrast, a eustatic change or event will have more or less the same scale and intensity at the global scale. Although this is theoretically true in that the rise in sea level to be expected will be the same everywhere, this fails at a chronologically modulated practical level, implicit within the sequence stratigraphic paradigm (cf. Catuneanu, 2006). Sequence stratigraphic "events" are never instantaneous, and, depending on the magnitude of the eustatic cycle, they may take significant geological time periods. This allows the interaction of local tectonics and sediment supply (in particular, but also several other factors) to interact with the eustatic rise, resulting in a host of cratonic to smaller scale relative sea-level change scenarios and the coeval manifestation of local transgression or regression. Thus, even a eustatic "event" may fail to meet the restrictive definition of a global scale event whose effects in the rock record are approximately equal around the world.

This paper will briefly examine different kinds of globally relevant Precambrian events, their probable chronological correlations, and their relevance to the theme of this special issue: first- and second-order global sequence stratigraphic correlations and accommodation curves for the Amazon, Congo, Fennoscandian, Kaapvaal, Pilbara, São Francisco, Singhbhum, Superior and Yilgarn cratons. In all such studies, accurate geochronology is a prerequisite, whatever the nature of the "event" itself.

\section{Development of geochronological methods and their application to the Precambrian rock record}

Geochronology is the science of determining the time elapsed since, or "age" for, formation, heating, cooling or re-crystallization events recorded within a geological sample. Dating of geological events has principally relied on the precisely known and constant rate of radioactive decay of the few key isotopes- ${ }^{87} \mathrm{Rb}$, which decays to ${ }^{87} \mathrm{Sr}$, ${ }^{40} \mathrm{~K}$ to ${ }^{40} \mathrm{Ar},{ }^{147} \mathrm{Sm}$ to ${ }^{143} \mathrm{Nd},{ }^{238} \mathrm{U}$ to ${ }^{206} \mathrm{~Pb}$ and ${ }^{235} \mathrm{U}$ to ${ }^{207} \mathrm{~Pb}$ - whose half-lives are comparable to the $10^{6}$ to $10^{9}$ year durations of the ages of interest. Each of these radioactive decay systems behaves differently within geological samples and the insight required to correctly interpret the results obtained from their application for geochronology has progressively accumulated during their extensive application.

The earliest widespread applications of isotopic methods for the geochronology of Precambrian events were undertaken in the 1950 's, with ${ }^{87} \mathrm{Rb}-{ }^{87} \mathrm{Sr}$ and ${ }^{40} \mathrm{~K}-{ }^{40} \mathrm{Ar}$ analyses of high $\mathrm{Rb}$ - and $\mathrm{K}$-bearing minerals, such as micas, isolated in bulk from individual rock samples. It was soon realized that, largely due to the mobility of $\mathrm{Rb}, \mathrm{K}$ and particularly of the noble gas ${ }^{40} \mathrm{Ar}$, plausible estimates of mineral formation age using this approach could only be obtained from high-purity mineral separates from samples with simple geological histories. Following publication of a key study by Compston and Jeffery (1959), the ${ }^{87} \mathrm{Rb}-{ }^{87} \mathrm{Sr}$ isochron method, in which analyses from a number of samples from a single rock unit were combined, became the preferred isotopic technique for the dating of Precambrian events. Prior to 1980, estimates of the formation ages of the Precambrian rocks of most continents were based largely on whole rock and mineral ${ }^{87} \mathrm{Rb}-{ }^{87} \mathrm{Sr}$ isochron dates. 
The ${ }^{87} \mathrm{Rb}-{ }^{87} \mathrm{Sr}$ isochron technique dates the time at which the dispersion in $\mathrm{Rb} / \mathrm{Sr}$ ratios in the samples occurred and relies on the validity of three key assumptions- all samples included on the isochron must have had identical ${ }^{87} \mathrm{Rb}-{ }^{87} \mathrm{Sr}$ formation ages, as well as the same initial ${ }^{87} \mathrm{Sr} /{ }^{86} \mathrm{Sr}$, and the ${ }^{87} \mathrm{Rb}-{ }^{87} \mathrm{Sr}$ isotopic system must have remained closed since formation. ${ }^{87} \mathrm{Rb}-{ }^{87} \mathrm{Sr}$ isochrons obtained on Precambrian igneous rock suites were commonly interpreted as dating the time of igneous crystallization, even though many of these suites had been metamorphosed to at least lower greenschist facies. It is now appreciated that both $\mathrm{Rb}$ and $\mathrm{Sr}$ can be mobile under relatively low metamorphic grade conditions (particularly within fine-grained volcanic lithologies) and even during extensive surface weathering. As a consequence of the common open-system behaviour of $\mathrm{Rb}$ and $\mathrm{Sr}$ during metamorphic disturbance, many of the ${ }^{87} \mathrm{Rb}-{ }^{87} \mathrm{Sr}$ isochron dates reported for igneous crystallization in earlier studies are probably best interpreted as minimum age estimates of the time of igneous crystallization, or as estimates for the time of metamorphic or hydrothermal disturbance. A further limitation of the ${ }^{87} \mathrm{Rb}-{ }^{87} \mathrm{Sr}$ isochron method is the relatively large uncertainties, typically $> \pm 50 \mathrm{Ma}$, that apply to these dates.

In the mid-1980's, the first limited geochronology investigations of Precambrian rocks using the ${ }^{147} \mathrm{Sm}^{143} \mathrm{Nd}$ technique were undertaken. It was initially hoped that this technique could overcome the problem of susceptibility to metamorphic disturbance that beset the ${ }^{87} \mathrm{Rb}-{ }^{87} \mathrm{Sr}$ and ${ }^{40} \mathrm{~K}-{ }^{40} \mathrm{Ar}$ dating techniques, as the rare-earth elements Sm and Nd are generally less mobile during metamorphism than the more reactive alkali and alkaliearth elements $\mathrm{Rb}, \mathrm{K}$ and $\mathrm{Sr}$ and the inert noble gas Ar. Unfortunately, due to the similar chemical properties and ionic radii of $\mathrm{Sm}$ and $\mathrm{Nd}$, the $\mathrm{Sm} / \mathrm{Nd}$ ratio is not greatly changed by most common fractional crystallization and magma differentiation processes, and the restricted range in the $\mathrm{Sm} / \mathrm{Nd}$ ratio encountered in co-genetic samples commonly limited the precision attainable by the ${ }^{147} \mathrm{Sm}^{-}{ }^{144} \mathrm{Nd}$ isochron method to $> \pm 50 \mathrm{Ma}$.

The susceptibility to disturbance of a radioactive decay system within a whole-rock sample is determined by parent or daughter element exchange, or loss from the most easily disturbed rock component or mineral structure present in the sample. However, radiometric decay schemes used for geochronology are more likely to remain closed systems on a mineral scale, provided the structure of the host mineral is sufficiently robust. As a consequence, most radiometric dating methods now rely on the dating of a chemically suitable mineral, with high parent/daughter ratio, that is isolated from a geological sample. Radiometric dates obtained from an individual host mineral can then be related to a specific event or process responsible for development of the observed mineralogy of the host rock. The high precision dates obtainable using the coupled ${ }^{238} \mathrm{U}$ and ${ }^{235} \mathrm{U}$ radioactive decay to ${ }^{206} \mathrm{~Pb}$ and ${ }^{207} \mathrm{~Pb}$ within high- $\mathrm{U}$ minerals were not widely exploited for geochronology until the mid 1980's. Zircon is a very common, highly resilient mineral that preferentially incorporates $\mathrm{U}$ and $\mathrm{Th}$ into, but excludes $\mathrm{Pb}$ from, its crystal structure during crystallization. The earliest $\mathrm{U}-\mathrm{Pb}$ zircon dating investigations used large numbers of zircon grains that were extracted from rock samples and dissolved and analyzed in bulk. It was later appreciated that, in part because of its resilience, different generations of zircon are commonly found in a single rock sample and techniques were refined in order to analyze fewer zircon grains. Methods were also developed to abrade the outer surface and the softer, radiation-damaged areas of zircon grains, in order to remove these zones of the grain from which radiogenic $\mathrm{Pb}$ may have 
been lost and to make the analysis more concordant. However, individual zircons may consist of core and rim materials with different crystallization ages. Development of the ion microprobe and laser ablation mass spectrometry dating techniques now allows analysis of $\mu \mathrm{m}$-scale portions of individual zircon crystals, enabling cores and rims of individual zircons with different crystallization ages to be dated separately with a routine precision typically better than \pm 10 Ma.

\section{Globally relevant events in the Precambrian (basinal) record}

In this section we review briefly the different major global-scale event-types, and provide succinct commentaries on each which focus on their often controversial origins, their fallibility as global markers within the Precambrian record, and their temporal characteristics.

\subsection{Supercontinent events}

The supercontinent cycle is a fundamental concept within geology and implicit within Phanerozoic sequence stratigraphy; additionally, it impacts strongly on inferred palaeoclimatic changes and biological evolution (e.g., Aspler and Chiarenzelli, 1998). The genesis of supercontinents has been seen as either reflecting assembly of a relatively large number of cratons with many sutures developing along collisional margins (Unrug, 1992), or repeated coalescence and separation of a relatively small number of large continental masses from at least $1.5 \mathrm{Ga}$ (Rogers, 1996). The latter author postulated a number of ancient continental masses (cf., "ancient nuclei" of Meert, 2002), of differing antiquity (Rogers and Santosh, 2002):

(a) "Ur" (c. 3.0 Ga; assembly of a core of Indian cratons, Dharwar, Bhandara, Singhbhum, with Kalahari, Western Dronning Maud, Napier and Pilbara);

(b) "Arctica" (c. 2.5 Ga; Aldan, Anabar/Angara, Slave, Rae, Greenland, Hearne, Nain, Superior and Wyoming cratons);

(c) "Atlantica" (c. $2.0 \mathrm{Ga}$; West Africa, Congo/Kasai, Guyana, Brazil, São Francisco and Rio de la Plata cratons);

(d) "expanded Ur" (>1.5 Ga; addition of Zimbabwe, Madagascar, Bundelkhand, Aravalli, Yilgarn, Kimberley, Gawler, and Eastern Australian terranes to Ur);

(e) "Nena" (c. $1.5 \mathrm{Ga}$; addition of Palaeoproterozoic (Ruban, 2007) Baltica continent and most of East Antarctica to Arctica).

In view of the complexities outlined above, and bearing in mind the lack of reliable palaeomagnetic data older than about $1.8 \mathrm{Ga}$ (e.g., Meert, 2002), one should rather consider supercontinents constrained by palaeomagnetic data sets of lesser antiquity. Piper (1976) first proposed a Palaeo-Mesoproterozoic supercontinent, based mainly on palaeomagnetic data. "Columbia", comprising an assemblage of most then-extant 
cratonic blocks, is postulated to have existed from $~ 1.9-1.5 \mathrm{Ga}$, with breakup commencing at $\sim 1.6 \mathrm{Ga}$ and continuing until about $1.4 \mathrm{Ga}$ (Rogers and Santosh, 2002). Meert (2002) made a critical study of the amount and quality of palaeomagnetic data used to evaluate the Columbia configuration, and came to the conclusion that it had only limited potential, with the supercontinent likely post-dating c. $1.77 \mathrm{Ga}$. Drifting, rotation and reassembly of most of the daughter fragments of Columbia led to formation of supercontinent Rodinia (e.g., Dalziel, 1997), marked by widespread sutures of the largescale, c. $1.0 \mathrm{Ga}$ Grenville orogeny (Rogers and Santosh, 2002). Although vigorous debate on detailed configuration of Rodinia continues (e.g., Weil et al., 1998), few doubt the existence of this cratonic assembly, nor the applicability of a widespread orogenic event, preserved on many different cratons today, to mark its assembly at about $1.0 \mathrm{Ga}$. Pangea, the youngest supercontinent at c. $0.25 \mathrm{Ga}$ (age of maximum development [cf., "maximum packing"]; Rogers and Santosh, 2009) essentially encompasses all the earlier cratons alluded to above (Fig. 2).

For proposed supercontinental assemblies $>\mathrm{c}$. $1.8 \mathrm{Ga}$, thus, recourse must be had to geological data, notably geochronology and structural data such as matching of mobile belts (e.g., Meert, 2002). A number of workers have discussed the merits of relatively speculative Neoarchaean supercontinents (e.g., Button, 1976; Piper, 1983; Gaál, 1992; Stanistreet, 1993; Cheney, 1996). Aspler and Chiarenzelli (1998) argued in favour of a Neoarchaean "Kenorland" assemblage (first postulated by Williams et al., 1991, for the assembled cratonic blocks of North America), and supported their arguments largely by chronological data. They also suggested an "expanded Kenorland" which possibly included the Baltic and Siberian shields, and speculated on a "southern" (modern latitudinal context) Neoarchaean-Palaeoproterozoic supercontinent. The latter is thought to have included a "Zimvaalbara" (cf. assembled Zimbabwe, Kaapvaal and Pilbara cratons; Stanistreet, 1993) block as well as the São Francisco, and Indian cratons. The Kenorland supercontinent is postulated to have undergone protracted breakup from c. $2.45-2.1 \mathrm{Ga}$, with dispersal from c. $2.1-2.0 \mathrm{Ga}$, related to a large-scale mantle upwelling (Aspler and Chiarenzelli, 1998). These authors proposed that the daughter fragments of Kenorland were reassembled as supercontinent Laurentia, which resembled its predecessor; Laurentia's assembly was marked by c. $2.0-1.8 \mathrm{Ga}$ orogenic belts, as proposed by Hoffman (1988) in a well known paper on the "United Plates of America". The presence of c. $2.7 \mathrm{Ga}$ greenstone belts on several cratons has raised the question of a possible supercontinent of that age (e.g., Bleeker, 2003). Bleeker and Ernst (2006) provided a reconstruction of an inferred Neoarchaean-Palaeoproterozoic Superia supercontinent, comprising the Superior, Kola-Karelian, Hearne and possibly also the Wyoming cratons, based largely on comparison of ages, geometry and palaeomagnetic character of dyke swarms.

\subsubsection{Commentary}

Discussion of supercontinents is dependent on viewpoints adopted for the antiquity of a Phanerozoic-style plate tectonic regime in the earlier part of the Precambrian epoch (e.g., discussion in de Wit, 1998). In this paper we subscribe to an overall framework whereby a Hadean Earth dominated by thermal magmatic processes gradually evolved to one where recognisable plate tectonics was pre-eminent and interacted with large scale mantle processes such as plumes. Within this hypothetical framework we subscribe to the 
probable validity of Trendall's (2002) "plughole model" of early crustal evolution which provides for a transition from thermally-dominated processes to a regime where plate tectonics became intimately associated with mantle-dominated processes. This general concept was summarised by Eriksson and Catuneanu (2004). The supercontinent cycle is seen by many workers to be directly related to the plume concept (as espoused by Condie, 2004a, b; Condie et al., 2001), similar to the ideas of Zhong et al. (2007), who discussed two modes of alternating mantle convection encompassing hemispheric upwellings and downwellings, which controlled c.1.0 Ga supercontinent assemblage and breakup. Recently, Santosh et al. (2009) have stressed the possibly crucial role of the tectosphere as opposed to the continental crust in supercontinental dynamics through time.

Data and techniques used to support postulated Precambrian supercontinental assemblies include geochronology, matching basin-fill stratigraphies or mobile belt segments on separate cratonic blocks, correlating widespread impact ejecta/fallout units (e.g., Glikson, 2008 for a recent example), and palaeomagnetic techniques (e.g., Pesonen et al., 2003). While demonstrating chronological equivalence or the presence of coeval impact spherule beds on separate cratons does not necessarily imply juxtaposition, and noting that matching basin-fills or mobile belts is not an exact science, it is often accepted that palaeomagnetic studies are the only really quantitative means of testing postulated relationships between Proterozoic continental blocks within any of the proposed assemblages. However, palaeomagnetic techniques are fraught with problems also, and many have argued against their application to terranes older than about $1.8 \mathrm{Ga}$ (e.g., Meert, 2002; see, however, Bleeker and Ernst, 2006; discussion in Eriksson et al., 2009a).

In such studies, it is necessary to separate primary and secondary magnetizations and to have accurate chronological data for palaeomagnetic poles (Meert, 2002). The latter author provides useful summaries of the two major methods of evaluating inferred supercontinental reconstructions: (1) rotate palaeomagnetic poles to a common reference frame and construct polar wander paths for known segments of the postulated supercontinents; (2) the "best fit" method, whereby individual palaeomagnetic poles are used to place the segments in their "correct" palaeolatitudinal positions and to evaluate their spatial relationships. It needs to be noted, additionally, that palaeomagnetic studies do not allow any palaeolongitudinal control (Meert, 2002), that deformed Precambrian successions commonly provide challenges in reconstructing palaeopoles, and that palaeomagnetic data do not indicate a specific hemisphere (Hartz and Torsvik, 2002). There is also uncertainty in aligning magnetic and geographic poles during the Precambrian.

While a lack of reliable palaeomagnetic data precludes a detailed analysis of this aspect of the proposed Neoarchaean Kenorland (or "Superia", cf., Bleeker and Ernst, 2006) supercontinent, comparison of the regional lithostratigraphy across the North American cratonic blocks as well as the Baltic and Siberian shields, including a widespread glacigenic horizon, makes a relatively compelling case for the possibility of such an amalgamation; this is also supported by a large geochronology data base (e.g., Aspler and Chiarznezelli, 1998). Work on precisely dated dyke swarms strongly supports this Superia/Kenorland supercontinent, consisting of Superior, Kola-Karelian, Hearne and likely also the Wyoming cratons (Bleeker and Ernst, 2006). While there is support for this possible supercontinent, centred on North American cratons, the case for a 
"southern" (modern parlance) equivalent is, at best, tenuous. The possibility of a Neoarchaean-Palaeoproterozoic "Zimvaalbara" assemblage has been debated in the literature, particularly by Cheney (1996), who used lithostratigraphic, sedimentary faciesbased and sequence stratigraphic arguments to motivate for a Kaapvaal-Pilbara ("Vaalbara") connection, to which he added the Zimbabwe craton and Grunehogna province from Antarctica. Cheney (1996) applied "sequence stratigraphy" through unconformity-bound units rather than using fully modern techniques such as in Catuneanu (2006). However, neither palaeomagnetic data (albeit of possible questionable reliability) nor detailed chronological data collected since, have supported the Vaalbara assemblage (e.g., Wingate, 1998; Nelson et al., 1999; Eriksson et al., 2005b). Eriksson et al. (2009a) reviewed the basic geology of possible "southern" cratons that may have been contiguous with Kaapvaal in the c. $3.1-2.8$ Ga period, within a hypothetical Kenorlandanalogy framework, and found no support for such a "southern" supercontinent (cf., Aspler and Chiarenzelli, 1998) at that time. Eriksson et al. (2009a) and Nelson et al. (1999) also stressed the alternative explanation for similarities in the geological character of ancient cratons, that they may reflect global events (e.g., superplume events, Condie 2004a; glaciation or eustatic events) rather than exclusively suggesting contiguity.

Nelson et al. (1999) examined the geology and in particular the chronology of Kaapvaal and Pilbara over the 3650-2200 Ma period, and found no evidence in favour of an amalgamation. It can thus be argued that a more reliable approach to examine potential fragments of possible early Precambrian supercontinents than palaeomagnetism is provided by comparison of the timing of geological events recorded on those daughter fragments (e.g., Nelson, 2008). The latter author utilized probability distribution plots of precise geochronological data to examine the evolution and possible spatial relationships between the Pilbara and Yilgarn cratons of Australia. Ongoing research by Ernst and colleagues into establishing Precambrian supercontinent reconstructions back to $2.6 \mathrm{Ga}$, through high-quality data now becoming available for the global LIP (large igneous province) record (section 3.2 below) is showing great promise (e.g., Ernst et al., 2005). Work by this team which is still under review indicates that Zimbabwe was probably part of the Neoarchaean Superia supercontinent and only became joined to Kaapvaal at about 2.0 Ga (R.E. Ernst, pers. comm., 2009).

\subsection{Mantle plume events}

Condie (2001, 2004a, b) defined superplumes (large mantle plume with distinct head and tail, thought to emanate from D" layer above core-mantle boundary) and superplume events. The latter are relatively short-lived $(\leq 100 \mathrm{Ma})$ events comprising many superplumes and smaller plumes which impinge on the base of Earth's lithosphere; in the course of these global-scale events, plumes and their products may become concentrated within mantle upwellings (Condie, 1998; Isley and Abbott, 1999; Condie, 2001; cf. Larson, 1991). The importance of plumes throughout Earth history (e.g., Condie, 1998; Isley and Abbott, 1999) is best supported by plume proxy evidence such as komatiites, picrites, flood basalts, and large dyke swarms (Isley and Abbott, 1999; Ernst and Buchan, 2002), with further evidence being provided by peaks in the occurrence of BIF, shallow marine sediments, black shales, and high values of the Chemical Index of Alteration (CIA; cf. Nesbitt and Young, 1982) (Condie, 2004a). 
A time series analysis of the occurrence of plume proxies in the geological record suggests a number of major superplume events, of inferred global and more local scale, including those at: $2.75-2.7 \mathrm{Ga}$ (global), $2.45 \mathrm{Ga}$ (particularly for juvenile crust formation in India and the North China craton), $2.1-2.15$ Ga (crustal formation in Guiana Shield and West Africa), 2.0-1.9 Ga (global), and 1.75-1.70 Ga (continental growth in Southern Baltica and in Laurentia) (Condie, 1992, 1998, 2004a; Eriksson et al., 2004a). The two superplume events which Condie (e.g., 2004a) interpreted to have been of truly global compass are those at c. $2.7 \mathrm{Ga}$ and c. $1.9 \mathrm{Ga}$ (Fig. 1), and these would presumably have had major effects on the preserved Precambrian rock record, such as outlined through the various proxies discussed in the preceding paragraph.

Ernst and co-workers (e.g., Ernst et al., 2004) have a less specific definition of plumes, wherein depth of origin is not constrained. Investigations of the LIP (essentially plume products) record over time indicates a semi-continuous occurrence, weak cyclicity over hundreds of millions of years, and on average, one LIP event per $20 \mathrm{Ma}$ (for the continental record; c. $10 \mathrm{Ma}$ for oceanic and continental LIP's) (Ernst et al., 2004). Ernst et al. (op. cit.) also supported the idea of clusters of some plumes into superplume events on the temporal scale.

Condie et al. (2009a) discussed mantle-plume related chronological control on granite events as well as on episodic growth of continental crust formation. Major peaks in granitic magmatism and inferred related mantle plume events at c. $2.7 \mathrm{Ga}$ and $1.9 \mathrm{Ga}$ were found by them to comprise much more complex sets of peaks in relatively close temporal proximity, and thus probably reflect mantle plume events (cf. mantle superplume events of Condie, 2001) comprising sets of plumes/superplumes. Condie et al. (2009a) thus defined seven igneous peaks or "events" which they are able to identify on at least five different cratons/continents: 3300, 2700, 2680, 2500, 2100, 1900 and $1100 \mathrm{Ma}$. These authors also identified additions of juvenile crust (based on $\mathrm{Nd}$ isotope distributions) at: 2700, 2500, 2120, 1900, 1700, 1650, 800, 570 and $450 \mathrm{Ma}$; this will also relate, at least partially, to inferred supercontinental cyclicity (section 3.1). Condie et al. (2009b) discussed global distribution of U-Pb ages of subduction-related granitoids and detrital zircons, and postulated that there was a marked episode (cf. "event" of relatively long duration as discussed in this paper) of significantly reduced magmatic activity across the planet at c. $2.45-2.2 \mathrm{Ga}$. This period shows an absence of arc-type greenstones, of tonalite-trondhjemite-granodiorite suites and only a single known LIP event, and is related by Condie et al. (2009b) to episodicity in the mantle thermal regime with concomitant stagnation of Earth's plate system. They suggested further, that palaeoatmospheric oxygenation (cf., "Great Oxidation Event" of c. $2.3 \mathrm{Ga}$; Lindsay and Brasier, 2004; Ohmoto, 2004) as well as the first global glacial event at c. 2.4-2.3 Ga may have resulted from this stagnation in the Earth's thermal and plate tectonic engines (Condie et al., 2009b). The postulate of global tectonic-mantle thermal stagnation from c. 2.45-2.2 Ga (Condie et al., 2009b) supports the hypothesis expressed by Eriksson et al. (2004a) that c. $2.7 \mathrm{Ga}$ and c. 2.2-1.8 Ga "superevents" (characterised by enhanced geodynamic activity globally) were separated by a period of relative tectonic quiescence on Earth. 


\subsubsection{Commentary}

The usefulness of superplume events as precisely timed global events for correlation between different Neoarchaean-Palaeoproterozoic cratons will be impaired by the commonly c. 100 Ma duration (e.g., Condie, 2004a) of such events. Condie et al. (2009a) similarly found that granitoid events and their related mantle plume events comprise a set of individual plumes and a complex of associated, chronologically related (c. $110 \mathrm{Ma}$ ) granitic occurrences. In this sense, mantle plume "events" are partially analogous to inferred early Precambrian supercontinent events, which likely took place over temporal scales well in excess of $100 \mathrm{Ma}$, and are also compatible with inferred durations of firstand second-order sequence stratigraphic cycles (e.g., Catuneanu et al., 2005). Ernst and co-workers have greatly improved the usefulness and accuracy of applications of the LIP record towards supercontinent reconstructions in the Precambrian in recent and ongoing work (e.g., Ernst et al., 2005). They are putting together "barcodes" for individual cratons of short-lived major magmatic events, and using precisely dated dyke swarms as piercing points in ancient Precambrian supercontinent reconstructions. Matching up such precisely dated dyke swarms' geometry on potentially previously adjacent supercontinent daughter fragments provides a powerful method.

\subsection{Impact events (impact spherule beds)}

Although only relatively few impact spherule beds have been found thus far within the early Precambrian rock record, their value (i.e. chronological precision as marker beds for intercratonic correlation) and their implications might be of fundamental importance. Given that the oldest known large impact structure on Earth, at Vredefort on the Kaapvaal craton, is 2020 Ma (e.g., Grieve, 1998) and bearing in mind the incomplete preservation of earlier continental crust, particularly in the Archaean, knowledge of pre$2.0 \mathrm{Ga}$ impact events is necessarily limited. Abbott and Hagstrum (2004) estimated that there could have been at least 350 global-scale impact events in the 3.8-2.5 Ga period, mostly presumably within the oceanic realms with concomitant preservation problems within the rock record. Eleven known spherule beds (Simonson et al., 2004, their table 1.3-1; Simonson and Glass, 2004) provide support for impact events earlier than Vredefort (see, however, Koeberl and Reimold, 1995, who disputed an impact origin for some examples of spherule beds at Barberton). Spherules are particles with internal textures and external shapes supporting genesis through quenching of silicate melt droplets after impact melting of target rocks. Some of them are estimated to have ascended up to $80 \mathrm{~km}$ into the stratosphere (Koeberl, 1992) before deposition in spherule beds (Abbott and Hagstrum, 2004; Simonson et al., 2004); wide dispersion across the globe and through reworking processes is thus to be expected.

The eleven beds summarised by Simonson et al. (2004) occur in the Pilbara and Kaapvaal cratons, with one in Greenland; c. 3.47 Ga spherule beds occur in both Kaapvaal and Pilbara, with four c. 3.24-3.26 Ga beds in the Barberton greenstone belt of the former craton. The Hamersley basin (Pilbara) succession contains four beds, two dated at c. $2.63 \mathrm{Ga}$ (Rasmussen and Koeberl, 2004; Rasmussen et al., 2005; Glikson and Vickers, 2007), and one each at $2.54 \mathrm{Ga}$ and $2.48 \mathrm{Ga}$; the Griqualand West sub-basin of the Transvaal Supergroup on Kaapvaal has a $>2.6,<2.65$ Ga bed (Simonson et al., 2004; Simonson and Glass, 2004; Hassler et al., 2005). The spherule-bearing beds are thin 
(centimetres to a few metres) and extend laterally over preserved distances varying mostly from several kilometres up to $330 \mathrm{~km}$; the two potentially correlated beds at c. 2.63 in Kaapvaal and Pilbara both persist laterally for $230 \mathrm{~km}$ (Simonson et al., 2004). Analogy with the K/T impact event and concomitant spherule occurrence globally (e.g., Smit, 1999) suggests that the c. $3.47 \mathrm{Ga}$ and c. $2.63 \mathrm{Ga}$ impact events may equally have been global in compass; however, the enclosing facies of the spherule beds indicate deposition mostly beneath wave base and extensive sedimentary, mass-flow and catatrophic (e.g. tsunami) reworking processes (e.g., Simonson, 1992; Glikson, 2001; Hassler and Simonson, 2001; Lowe et al., 2003). The geochemistry of the spherules suggests they might be distal rather than proximal deposits relative to the impact sites themselves (Simonson et al., 2004).

\subsubsection{Commentary}

As outlined above, there is evidence to support two globally correlatable impact events, one at c. $3.47 \mathrm{Ga}$ and one at c. $2.63 \mathrm{Ga}$, with direct evidence available from at least two cratons, Kaapvaal and Pilbara (coincidentally amongst the two oldest such). The expected wide dispersal of spherules ejected high into Earth's atmosphere and stratosphere and the extensive reworking of these particles once they fall to earth and ocean suggests they would make excellent global event markers for the purposes of correlating early Precambrian cratons and their associated basin-fill successions. The observed correlation between Kaapvaal and Pilbara might also merely reflect a more local impact and dispersal event depending upon the veracity of a possible amalgamation between these two cratons (discussed above in section 3.1); however, as noted there, evidence does not support such contiguity, at least for the period c. 3650-2200 Ma which includes the noted two impact events at $3.47 \mathrm{Ga}$ and $2.63 \mathrm{Ga}$.

Apart from potentially providing very precise marker beds across various early Precambrian cratons, impact events might also have had far more fundamental influences on Earth evolution and particularly on the sedimentary record preserved on those cratons. Glikson and Vickers (2007; see also, Glikson 2006) noted the spatial relationship for many of the known Archaean-Palaeoproterozoic impact spherule beds and succeeding BIF or clastic-ferruginous sediments, and suggested that igneous activity was triggered by large impact events to result in seawater enriched in ferrous iron. They particularly applied this model to the c. 3.47, 3.26, 3.24, 2.63 and $2.56 \mathrm{Ga}$ beds (see also Glikson, 2008). In the latter paper, Glikson argued that the c. 3.26 and 3.24 impacts within the Archaean Barberton greenstone belt succession were related to fundamental changes in lithostratigraphy. Impact events have also been tied to enhanced plume activity or stronger plume activity within the framework of an active superplume event (e.g., Abbott and Isley, 2002); this would be particularly applicable to the Archaean plume-impact record (Abbott and Hagstrum, 2004).

In addition to precise marker beds in the form of spherule beds, impact events may thus also have provided far more robust and widespread sedimentation events on Earth, potentially preserved on many more cratons than the impact spherule beds themselves. A possible genetic link between impact events and global igneous activity activating ironrich source areas leading to enrichment of ferrous iron in the global Precambrian ocean (e.g., Glikson, 2006, 2008) also has implications for correlation of major BIF and clastic- 
ferruginous deposits across the Precambrian cratons. This topic is discussed further in section 4.5 below.

\subsection{Major orogenic events (belts)}

The construction of detailed and well-constrained pressure-temperature-time (P-T-t) paths is crucial in deciphering the tectonic evolution of orogenic belts. A P-T-t path is constructed via the application of thermobarometric methods (e.g., Powell and Holland, 2008) to metamorphic mineral parageneses to determine the P-T evolution, and then the path is calibrated as a function of time using geochronological data (e.g., Mahan et al., 2008; Millonig et al., 2008). A clockwise, prograde increase in $\mathrm{P}$ and $\mathrm{T}$ provides evidence for crustal thickening or accretion associated with collisional tectonics (e.g., England and Thompson, 1984; Zeh et al., 2004). Recognising such processes over a regional or global scale within a given period of time provides robust evidence for crustal contiguity and craton formation. A single collisional orogen would be deemed a significant regional or inter-cratonic event. However, the contemporaneous development of numerous, geographically-distinct orogens would be a globally significant super-event, for example, if they contributed to the assembly of a supercontinent. This is clearly exemplified by the ubiquity of Neoproterozoic tectono-metamorphic events that led to the formation of Gondwana.

The assembly of Gondwana is generally discussed in terms of the amalgamation of East Gondwana (Fig. 3; India, East Antarctica, Madagascar, Australia and Sri Lanka) and West Gondwana (Fig. 3; Africa and South America) (e.g., Stern, 1994; Squire et al., 2006). However, as stipulated by Meert (2003) and Meert and Lieberman (2008), such a view oversimplifies the true nature of this super-event. The assembly of Gondwana resulted from a series of complex orogenic events spanning the interval 940-530 Ma (Meert, 2003; Tohver et al., 2006; Gray et al., 2007; Vaughan and Pankhurst, 2008). Figure 3 illustrates the main sutures related to the formation of Gondwana, which can be subdivided into three main orogenic belts: (1) the Brasiliano-Damara orogen (the assembly of western Gondwana), (2) the Kuungan orogen (the assembly of eastern Gondwana), and (3) the East African orogen (related to the suturing of East and West Gondwana) (e.g., Meert and Lieberman, 2008). However, this broader subdivision is still an oversimplification. For example, Figure 3 illustrates that the Brasiliano-Damara orogen is composed of numerous orogenic belts, including but not exclusively, the Hoggar, the Luffilian arc, the Damaran belt, the Gariep belt, the Katagan-Zambezi belt, the Arauguaia and the Aracuai belts. Whilst the causal link between all of these orogens is the assembly of western Gondwana, each orogen is distinct, forming at separate times due to the collision of different cratonic fragments (Vaughan and Pankhurst, 2008). This reasoning can also be applied to eastern Gondwana and the concurrent amalgamation of east and west. Despite many authors having oversimplified the assembly of Gondwana the evidence from different mobile belts, when viewed holistically, can only lead to one conclusion: the different cratonic fragments illustrated in Figure 3 were amalgamated in the Neoproterozoic to form the supercontinent Gondwana. Similarly, the widespread occurrence of Grenvillian orogens (c. 1300-1000 Ga) is used as evidence for the formation and existence of the Mesoproterozoic supercontinent Rodinia (e.g., Rogers and Santosh, 2002; Meert and Torsvik, 2003). However, the evidence from older 
Mesoproterozoic-Archaean orogenic belts becomes less robust and increasingly more complex to unravel and interpret (as discussed below).

\subsubsection{Commentary}

P-T-t paths from Phanerozoic and Neoproterozoic orogens are relatively simple to construct and interpret. They provide robust and undisputable evidence of continental or accretionary-type collision (e.g., Fig. 3). However, it has been shown above that even the well studied formation and evolution of the Gondwana supercontinent involved several different groups of orogenic belts, of different ages, and further that within each group, several individual orogenic belts of different ages are implicit. Simplistic modelling of orogenic belts across several cratons will thus not provide an easy panacea to attempts at global correlations within the Neoproterozoic or Phanerozoic.

When applying this to even older Precambrian mobile belts, it should be noted that many high-grade Mesoproterozoic-Archaean terranes have undergone a protracted, polyphase evolution involving at least two high-grade tectono-metamorphic events (e.g., Ouzegane et al., 2003; Boshoff et al., 2006; Perchuk et al., 2008). The problems related to the interpretation of Mesoproterozoic-Archaean high-grade terranes are exemplified by the controversial Limpopo Belt of southern Africa. Traditionally there have been two contrasting schools of thought regarding the tectono-metamorphic evolution of the Central Zone (CZ) and the entire Limpopo Belt (e.g., Rigby et al., 2008a). One camp has argued that the data collectively indicate that the $\mathrm{CZ}$ underwent deformation and metamorphism at c. 2.0 Ga (Kamber et al., 1995; Holzer et al., 1996, 1998; Kröner et al., 1999; Schaller et al., 1999; Zeh et al., 2004, 2005; Rigby et al., 2008b). Conversely, Van Reenen et al. (1987), McCourt and Vearncombe (1992), Roering et al. (1992), McCourt and Armstrong (1998), Bumby et al. (2001) and Bumby and Van der Merwe (2004) have advocated that the $\mathrm{CZ}$ and the entire Limpopo Belt formed during a single, Neoarchaean, high-grade event that was initiated by the collision of the Kaapvaal and Zimbabwe cratons. However, recent studies (Boshoff et al., 2006; Zeh et al., 2007; Perchuk et al., 2008; Van Reenen et al., 2008; Millonig et al., 2008; Gerdes and Zeh, 2009) have unequivocally demonstrated that parts of the $\mathrm{CZ}$ have undergone a series of complex and temporally-discrete events, which include the formation and subsequent anatexis of the Sand River Gneiss at 3.24-3.12 Ga (Zeh et al., 2007; Gerdes and Zeh, 2009), structural, metamorphic and magmatic events at 2.65-2.51 Ga (e.g., Boshoff et al., 2006; Van Reenen et al., 2008; Millonig et al., 2008) and a final 2.03 Ga metamorphic overprint (e.g., Boshoff et al., 2006; Zeh et al., 2007; Perchuk et al., 2008; Van Reenen et al., 2008; Gerdes and Zeh, 2009).

Despite these advances interpretation of the tectonic evolution of the Limpopo Belt still remains controversial. The main problem with the superposition of numerous tectono-metamorphic events relates to the correct identification of discrete structures and metamorphic mineral assemblages, which will adequately reflect a polymetamorphic history. For example, Perchuk et al. (2008) did not recognise two discrete mineral assemblages in their samples from the CZ. They postulated that the later metamorphic overprint produced the same mineral assemblage as the first and that the only change was the composition of the pre-existing minerals. However, Rigby (2009) argued that a reliance on compositional zoning profiles from polymetamorphic samples may lead to erroneous P-T estimates and subsequently a misinterpretation of the tectonic evolution. 
Additional problems relate to the interpretation of geochronological data (e.g., Van Reenen et al., 2008). For example, zircons extracted from a polymetamorphic rock may yield two distinct age populations, but without directly relating those data to either a metamorphic or magmatic event, any subsequent interpretation may be flawed. Boshoff et al. (2006) and Van Reenen et al. (2008) advocated an integrated D-P-T-t approach whereby discrete structures should be linked to specific mineral assemblages forming at a particular time. In theory, this approach should provide reliable data but actually implementing the approach in practice is often fraught with difficulty. Unravelling the complexities of high-grade polymetamorphic terranes remains the main challenge of many metamorphic petrologists.

\subsection{Chemochronologic events}

Weighing the validity of palaeo-atmospheric models and relating these to major inferred chronological changes in the composition of the Precambrian atmosphere and hydrosphere are fraught with difficulty and divergent viewpoints, based on essentially the same set of somewhat equivocal geological, palaeontological, and bio-geochemical data (e.g., Eriksson and Altermann, 2004a; Fig. 1). Ultimately, Earth's atmosphere and hydrosphere derive from the mantle and outgassing therefrom, with biological processes and evolution playing a critical associated role, as did also, the supercontinent cycle (cf. plate tectonics) and mantle plumes (Eriksson et al., 2004b). Greatly contrasting viewpoints on early Precambrian atmospheric evolution have been predicated on a sedimentary rock record where post-depositional influences in a system which cannot necessarily be considered closed, might have been significant (Eriksson and Altermann, 2004b).

The classic and certainly more popular model of Precambrian atmospheric evolution is that espoused by Cloud (1968), Walker (1977), Holland (2002), Kasting and Siefert (2002) (sometimes, thus, termed the "C-W-H-K model"; Ohmoto, 2004). This model encompasses: origin of life under a reducing atmosphere; minor rise of oxygen at 3.0 or $2.8 \mathrm{Ga}$ (e.g., Rye and Holland, 2000; Kasting and Siefert, 2002); a "Great Oxidation Event" at some time between about 2.3 and $2.0 \mathrm{Ga}$ with concomitant emergence of the eukarya; anoxic oceans until c. $0.6 \mathrm{Ga}$ except for the upper, photic (defined as $<$ c. $100 \mathrm{~m}$ water depth in the global ocean) portions; pre-1.8 Ga oceans with high $\mathrm{Fe}^{2+}$ and low $\mathrm{H}_{2} \mathrm{~S}$, those from c. $1.8-0.8 \mathrm{Ga}$ showing the reverse, and at c. $0.6 \mathrm{Ga}$, oceans became $\mathrm{SO}_{4}{ }^{2-}$ rich and $\mathrm{H}_{2} \mathrm{~S}$ - poor (e.g., Bjerrum and Canfield, 2002; Ohmoto, 2004). The main alternative model is the so-called "D-O" model (cf., Dimroth and Kimberley, 1976; Lasaga and Ohmoto, 2002) which postulates a single, early (soon after c. $4.0 \mathrm{Ga}$ ) rise in palaeo-atmospheric oxygen (Eriksson and Altermann, 2004b).

A major field of investigation has been the study of palaeo-atmospheric oxygen; due to the influence which oxygen has on the geochemical cycles of sulphur, carbon and other elements, carbon and sulphur isotopes are commonly used as proxies for inferred Precambrian palaeo-redox (e.g., Ohmoto, 2004). A generalised carbon isotope curve for the geological time scale is shown in Figure 4, with two major positive oxygen excursions at c. $2.3 \mathrm{Ga}$ (the "Lomagundi Event" or "Great Oxidation event") and c. 0.65 Ga (the so-called "Neoproterozoic event") (Lindsay and Brasier, 2004). 
Another related field of study has been the chronological distribution of the iron formations, held by many to at least partially reflect changes in atmospheric composition as Earth and its biochemical systems evolved: (1) early, poorly developed BIF (Algomatype) associated with greenstone belts and a reducing atmosphere from c. 3.8 Ga to the Neoarchaean; (2) a c. 2.5 Ga peak in BIF abundance, marked by the Superior-type iron formations from c. $2.7-2.3 \mathrm{Ga}$ (and especially those of the Kaapvaal and Pilbara cratons); (3) followed by the granular IF, which peaked at about $1.8 \mathrm{Ga}$; (4) a long hiatus from c. 1.6 - 0.6 Ga with limited Neoproterozoic IF (e.g., Trendall and Blockley, 2004).

Debate on the evolution of atmospheric oxygen in the Precambrian is necessarily founded upon observations of modern oxygen fluxes and sinks, summarised admirably by Ohmoto (2004). It is common knowledge that atmospheric oxygen is essentially biological in origin through the well known photosynthesis equation: $\mathrm{CO}_{2}+\mathrm{H}_{2} \mathrm{O}=\mathrm{CH}_{2} \mathrm{O}$ $+\mathrm{O}_{2}$. However, exposure of the resultant organic matter to the atmosphere and surface water, through several pathways, results in decomposition of the organic matter and consumption of an equal amount of oxygen as produced through photosynthesis (Ohmoto, 2004). As a result, all atmospheric oxygen is recycled through these pathways about every 3000 years, and the present-day atmosphere is in an almost steady-state balance. The only way to accumulate oxygen over the long term in the atmosphere is by removal of organic matter, mainly through burial of organic carbon in sediments, with marine sediments being by far dominant over terrestrial carbon burial; approximately $0.14 \%$ of current organic matter formed in the oceans is thus lost (Ohmoto, 2004). If long term production of atmospheric oxygen is essentially controlled by burial of organic-rich marine sediments, its long term consumption can be ascribed to oxidation of reduced volcanic gases, and oxidation of fossil carbon (kerogen) during soil formation from precursor sedimentary rocks (Holland, 1978; Lasaga and Ohmoto, 2002; Ohmoto, 2004).

\subsubsection{Commentary}

Taking the fundamental facets of the current oxygen cycle as outlined above, and applying them to the Precambrian rock record opens up hypothetical roles for both plate tectonics and mantle (plume) processes to significantly influence palaeo-atmospheric evolution over time. Mantle degassing and occurrences such as large plumes and superplume events will thus theoretically have the potential to increase consumption of oxygen (through oxidation of volcanic greenhouse gases), while plate tectonics through the supercontinent cycle can potentially bury large amounts of shallow marine successions bearing organic remains, thereby reversing such a consumptive trend and enhancing atmospheric oxygen accumulation. This apparently simple large scale model will nevertheless be very complex in detail due to highly divergent (and highly debated, at least in the case of plate tectonics) rates of the contributing first-order genetic processes over Precambrian time (e.g., discussion in Eriksson and Catuneanu, 2004). In addition, Ohmoto (2004) stressed the potential role of two important negative feedback mechanisms, especially if they become coupled: (1) the burial flux of $\mathrm{C}_{\text {org }}$ is dependent on $\mathrm{O}_{2}$ in the sense that a decrease in the latter in the atmosphere must result in a greatly enhanced burial flux of organic-rich sediments - the resultant increase in oxygen production flux will be up to seven times the decrease in atmospheric oxygen; (2) consumption of atmospheric oxygen by oxidation related to soil genesis is equally inversely related to $\mathrm{pO}_{2}$ (Ohmoto, 2004). 
The negative feedback mechanisms and the present-day essentially steady-state oxygen balance, if considered together, suggest that palaeo-atmospheric oxygen should have tended to move towards restoration of equilibrium if severely disturbed by a set of geological conditions. When this hypothesis is viewed in relation to the global carbon isotope curve through time (Fig. 4), it can be seen that this curve was very flat and had few known perturbations in the Archaean (Lindsay and Brasier, 2004); as a caveat, the limited data base may have affected this apparent character. An analogously muted variation is seen for $\delta^{13} \mathrm{C}$ for the later part of the Palaeoproterozoic and the Mesoproterozoic. However, highly variable carbon isotope values are recorded for marine sediments from c. $2.35-2.0 \mathrm{Ga}$ and from c. $0.9-0.5 \mathrm{Ga}$ (Fig. 4). These were also periods marked by inferred major plate tectonic reorganisations, supercontinent events, mantle plume and superplume events as well as glaciation, possibly of global scale. Significant disturbance of Earth's natural systems is evident at these times (e.g., Eriksson et al., 2004a). It is even possible that large scale orogenic uplift of carbon-bearing marine sediments during supercontinental amalgamations could have reversed any atmospheric oxygen gains which occured when those sediments were buried in deeper marine settings - this might also have contributed to $\delta^{13} \mathrm{C}$ oscillations related to supercontinental activity as per the Lindsay and Brasier (2004) model.

The question which arises here is: to what extent can the postulated "Great Oxidation Event" (Fig. 1) in the CWHK model discussed above be related to purely biochemical evolution of the palaeo-atmosphere, and to what degree might the observed extreme variation in the $\delta^{13} \mathrm{C}$ curve (Fig. 4) reflect endogenic processes such as the interaction of the supercontinent cycle and mantle (plume) processes? While many workers (possibly even a majority) globally still support an essentially purely atmospheric-hydrospheric model of biochemically-driven change in the Precambrian atmospheric make-up (i.e., thus following the basic tenets of the CWHK model discussed above), there is a growing school of thought that sees larger-scale first-order processes such as the supercontinent cycle being the predominant driver and even determinant of Precambrian atmospheric evolution (e.g., Lindsay and Brasier, 2004). The latter authors did not see the global oxygen isotope $\left(\delta^{13} \mathrm{C}\right)$ curve as necessarily being a proxy for global redox change in the Precambrian, but rather saw it as a reflection of the interaction of plate tectonic processes and mantle thermal events inherent in the release of Earth's endogenic energy. Analogously, Condie et al. (2009b) found that the "Great Oxidation Event" (as well as the first global glaciation at about the same time) was related to stagnation of global thermal and plate tectonic regimes.

Similarly, viewpoints on another commonly held proxy for estimating changes in the Precambrian atmospheric oxygen content, the chronological distribution of iron formation occurrence, are changing. Although models for BIF generation are variable, most agree that iron (c. 10-20 ppm dissolved ferrous Fe) and silica of fumarolic origin remained in solution for lengthy periods, with Archaean sea water enriched in iron only below the pycnocline; these chemical deposits accumulated in gently subsiding, large, distal (water depth $>500 \mathrm{~m}$ ) shelf basins (e.g., Trendall and Blockley, 1970, 2004). An iron- and Eh-stratified model is widely accepted, whereby either deep iron-rich ocean water upwelled onto the shallow shelves (cf., Holland 1973, 1984; Klein and Beukes, 1989) or the pycnocline was situated close to the depths of these outer shelf basin-floors, to enable large-scale deposition of the iron formations in such depositories (Trendall and 
Blockley, 2004). The latter authors emphasized that this stratified ocean model decouples IF deposition from being a proxy for palaeo-atmospheric oxygen, as sedimentation essentially takes place without direct influence from the extant atmosphere. Any potential relationship between IF deposition and $p \mathrm{O}_{2}$ would presumably also have been complicated by iron acting as a sink for hydrospheric oxygen produced by the large carbonate platforms commonly adjacent to many major iron-depositing basins of Neoarchaean-early Palaeoproterozoic age (i.e., the Hamersley basin of Pilbara and the Transvaal basins of Kaapvaal; e.g., Altermann and Nelson, 1998; Nelson et al., 1999).

The temporal distribution of BIF abundance taken together with the model outlined in Trendall and Blockley (2004) provides some support for a hypothesis of NeoarchaeanPalaeoproterozoic atmosphere-hydrosphere evolution, whereby the "chemical fertility" of the oceans over a relatively long period of time contrasted with shorter-lived basinforming conditions. The latter were essentially controlled by a combination of plate tectonics and mantle thermal processes and produced basins to accommodate chemical sediment deposition by carbonate platforms and upwelling Fe-rich deep ocean water encountering shallower shelves (or a pycnocline at approximately this depositional level). This postulate could explain why the "peak" in IF abundance was so broad, why IF deposition in various types and abundances occurred over such a long time period, and the c. 2.5 Ga peak may then reflect crustal growth rates and concomitant global eustasy combining to form many basins of suitable depth conditions for IF formation at approximately the Archaean-Proterozoic contact.

This viewpoint would obviously contrast with purely biochemical ideas on palaeoatmopsheric evolution whereby the c. $2.5 \mathrm{Ga}$ peak is seen as reflecting change in hydrosphere and atmosphere chemistry with little fundamental influence thereon from tectonic and mantle processes. In this paper, we postulate that a more holistic combination of longer term (i.e., more gradual) chemical change in hydrosphericatmospheric compositions interacted with first-order changes in the supercontinent cycle and the rates of its underlying fundamental processes, to produce what is seen in the rock record (cf., Trendall and Blockley, 2004). In the same vein, the "Great Oxidation Event" can be seen as reflecting perturbations in long-term tectono-thermal stability which caused rapid fluctuations in organic carbon burial and removal from the atmospherichydrospheric system, thus causing the observed disturbances in $\delta^{13} \mathrm{C}$ patterns over time (Fig. 4).

It is thus possible that any such oxidation event reflects a somewhat analogous interaction between longer term biochemical cycles on earth with shorter-lived supercontinent cycles. Eriksson et al. (2009b) have recently suggested that a predominantly reducing atmosphere may have continued for much longer periods than thought, from c. $2.3 \mathrm{Ga}$ until about $1.8 \mathrm{Ga}$, at least for some cratons (such as Kaapvaal, from whence they provide supporting data for their hypothesis). Sheldon (2006) has used a new model based on mass balance of palaeosol weathering to postulate that $\rho \mathrm{CO}_{2}$ remained consistently high from c. 2.5-1.8 Ga. These views again support the hypothesis that biochemical change in the Precambrian (or at least Palaeoproterozoic-Neoarchaean period) might have been a gradual process rather than one subject to sudden (geologically speaking) events, and that this gradually evolving chemical system in Earth's atmosphere-hydrosphere interacted with varying rates of supercontinental cycles to produce observed patterns in the sedimentary rock record geochemistry (Fig. 1). Meert 
and Tamrat (2004) summarised evidence in favour of and genetic models to explain highly variable and specifically very rapid rates of plate motion; they concluded that mantle plumes formed beneath supercontinents with thick tectospheres 200-400 Ma after assembly can lead to these rapid rates of movement, particularly for the Neoarchaean supercontinental events. These ideas follow the earlier work on the geodynamics of supercontinents and their underlying mantle, as well as concomitant eustatic changes (e.g., Gurnis, 1988; Gurnis and Torsvik, 1994; Honda et al., 2000). As fragmentation and dispersal of the supercontinent's cratons takes place, their movement off geoid highs will commonly result in first-order transgressive events, lagging supercontinental rifting events by time periods of the order of c. $50 \mathrm{Ma}$, at least for the Neoproterozoic.

\subsection{Glacial events}

Theoretically, a widespread glacial deposit provides a very good potential means of inter-craton or even inter-continent correlation; however, as discussed briefly below, there are many complexities involved. Of all the earlier Precambrian sedimentary environments and their products, glacial sediments perhaps most closely resemble their Phanerozoic-Modern counterparts in terms of facies and detailed characteristics; however, in direct contrast, models for the formation of Precambrian glacial deposits remain highly divergent and often contentious (e.g., Eriksson et al., 1998; Aspler and Chiarenzelli, 1998). Exacerbating application of often poorly preserved (due to postglacial reworking by a host of processes) glacial deposits to supercontinent reconstructions, is the thermal regime at the base of ice sheets and major glaciers (e.g., Menzies, 1995), with cold-based glaciers and ice sheets of large lateral extent potentially leaving little or no record of their presence (e.g., Holmund and Näslund, 1994; Kleman, 1994).

The application of glacial deposits to intracontinental correlations of Precambrian successions has enjoyed a long history (e.g., Palaeoproterozoic Huronian and Snowy Pass Supergroups in North America; Blackwelder, 1926; Coleman, 1926). Glacial deposits and their inferred regional to larger scale (global?) correlations are much better studied for the Neoproterozoic and its supercontinents (e.g., Young, 1992, 1995; Li et al., 1995, 1996). Two major Precambrian glacial episodes are recorded from the rock record, for the Palaeoproterozoic (dated at c. 2.4-2.2 Ga; Fig. 1) and the Neoproterozoic (dated at c. $800-540 \mathrm{Ma}$ ). In contrast to these demonstrably relatively widespread glacial events, possible inferences of earlier cold climate events within the Archaean rest on a limited record of apparently localised (mountain-sourced?) glaciation (e.g., the compendium of Hambrey and Harland, 1981; more specifically, Page, 1981 and Von Brunn and Gold, 1993).

Palaeoproterozoic glacial deposits occur most prominently within the Huronian Supergroup of Ontario, where three glacigenic units occur, separated by fairly large thicknesses of non-glacial lithologies; the lower two units (Ramsay Lake and Bruce Formations) are relatively localised and characterised by large amounts of reworked Huronian detritus from underlying formations, while the upper unit, the Gowganda Formation, is much more extensive and characterised by detritus derived largely from Archaean rocks of the Superior Province (e.g., Young, 2004). A very similar succession of rocks including three analogous glacigenic units is found in the Snowy Pass 
Supergroup in Wyoming, USA (e.g., Aspler and Chiarenzelli, 1998; their Fig. 5). The uppermost glacial unit within these two well correlated North American successions also occurs more widely within that region, as for example in the apparently periglacial Padlei Formation of the Hurwitz Group (Hearne Province) (Aspler and Chiarenzelli, 1998). This widespread uppermost glacial unit supports the concept of a large continental ice sheet over much of North America (e.g., Young, 1970, 1973) or even wider (e.g., Ojakangas, 1988) during the Palaeoproterozoic.

Further Palaeoproterozoic glacigenic rocks are known also from Finland (e.g., Marmo and Ojakangas, 1984; Strand and Laajoki, 1993), the Pilbara craton (e.g., Trendall, 1981; Martin, 1999) and from the Kaapvaal craton (e.g., Visser, 1981). There would appear to be only one glacial event in the Palaeoproterozoic with a large enough distribution to be considered in any way global, and its age is as yet only imprecisely determined as between 2.4 and 2.2 Ga (Young, 2004). The application of the Proterozoic glacial events to inter-cratonic correlation for the Precambrian is weakened by the difficulties in their precise dating, as well as, in the case of the Neoproterozoic, disagreement over the number and correlation of glacial units (cf., Young, 2004).

Two major periods of glaciation are generally recognised in the Neoproterozoic, based largely on three distinct negative $\delta^{13} \mathrm{C}$ anomalies: the Sturtian comprising two separate glaciations (c. 758-741 Ma and c. 723-712 Ma); and the Marinoan period (c. 590-560 Ma), followed by a possible fourth negative $\delta^{13} \mathrm{C}$ excursion marking the c. $560 \mathrm{Ma}$ Moelv glaciation (e.g., Frimmel, 2004). Although the Neoproteorzoic glacial deposits are widespread and are preserved on all the continents, a common lack of reliable age data has resulted in correlation resting largely on the carbon isotopic anomalies, thereby promoting a range of interpreted correlations.

\subsubsection{Commentary}

Interpretation of the causes of glaciation within both Palaeoproterozoic and Neoproterozoic remain contentious, complicated by arguments against and for the validity of palaeomagnetic data of variable antiquity (see also discussion in section 3.1), and argued vigorously by proponents and critics of the "snowball Earth hypothesis" (SEH). The SEH (e.g., Kirschvink, 1992; Hoffman et al., 1998) is an elegant thesis, which propounds that several major glacial episodes occurred in Earth's history when total glaciation of continents took place together with frozen oceans, probably caused by a combination of reduced solar luminosity (Palaeoproterozoic), runaway albedo consequent upon continental assemblages and initial ice development, all likely related to palaeo-atmospheric changes resultant upon supercontinental cyclicity. The absence of effective weathering as a carbon dioxide sink as well as minimal to zero photosynthetic drawdown of greenhouse $\mathrm{CO}_{2}$, allied to continued volcanic degassing in the deep oceans, led to melting of the global ice masses as fast as they had formed, with rapid deposition of "cap carbonates" through enhanced oceanic alkalinity, above glaciomarine deposits. Subsequent deposition of BIF followed due to oceanic waters enriched in iron during continuous fumarolic activity beneath frozen ocean surface waters (e.g., Eriksson and Altermann, 2004 a).

Fast and highly variable plate motions (cf., Meert and Tamrat, 2004) may have led to rapid consumption of organic carbon in shallow oceans as supercontinents assembled (following the Lindsay and Brasier, 2004 model discussed above, in section 3.5), leading 
to atmospheric oxidation and reduction of greenhouse states at the start of the inferred SE events. Similarly, palaeomagnetic evidence for low palaeolatitudes (e.g., Harland and Bidgood, 1959; Harland, 1964; Embleton and Williams, 1986; Schmidt et al., 1991; Schmidt and Williams, 1995; Sohl et al., 1999) as well as glaciation near sea level (e.g., Young, 2004) provide further support to the SE hypothesis.

Obviously such glacial events as inherent in the SEH, characterised by a combination of major chemostratigraphic changes as well as a relatively unique succession of sedimentary rock types, never mind presumed palaeontological markers, provide attractive possibilities as fundamental geological events to help correlate between Proterozoic cratons. However, opponents of the theory cite a significant number of arguments based on evidence from the rock record, against the SEH (e.g., Williams, 1975, 1986, 1998, 2004, 2008; Williams et al., 2008; Young, 2004): (1) thick successions of diamictites with associated water-laid deposits; (2) evidence supporting glacial cycles and eustasy; (3) the combination of tidalites, tidal rhythmites, and thick glaciomarine successions indicates unfrozen seas over significant areas; (4) evidence for strong seasonality in glaciogenic deposits; (5) indications of gradual palaeoclimatic changes at the start and end of Proterozoic glaciogenic events rather than the rapid and extreme changes inherent in the SEH; (6) a lack of high latitude Proterozoic glacial deposits; (7) cap carbonates and BIF within the expected stratigraphic succession from SE events are not that common, and the stratigraphic position, facies and chemistry of these chemical rock types can equally be explained through alternative genetic models, especially related to rifts as supercontinents begin to break up (e.g., summary in Eriksson and Altermann, 2004b). A recent comparison of Neoproterozoic glaciogenic units with Phanerozoic glacial deposits also provides a strong case against the SEH (Etienne et al., 2008).

Of the three Palaeoproterozoic glacial units found within North America, only the second is succeeded by carbonate rocks (e.g., Aspler and Chiarenzelli, 1998), thus not supporting the pristine version of the SEH very well. The possibility that the Palaeoproterozoic glaciation was associated with low palaeolatitudes has been discussed by a number of authors (e.g., Evans et al., 1997; Williams and Schmidt, 1997), in support of the SEH, bearing in mind the fallibility of the palaeomagnetic method in such ancient rocks (see section 3.1). While the Palaeoproterozoic glacial deposits show few spatial relationships to either cap carbonates or BIF as required by the SEH, their ages range over about $200 \mathrm{Ma}$ (Young, 2004) (Fig. 1), a shorter period than that for the Neoproterozoic glacial deposits.

As pointed out by Young (2004), the Neoproterozoic glacigenic rocks are very difficult to date (e.g., Fairchild and Kennedy, 2007), range in age over about $260 \mathrm{Ma}$, and there is also a lack of consensus on the number of such events; however, demonstrating their contemporaneity forms a cornerstone of the SEH. This is equally so for the Namibian examples which formed the basis for Hoffman et al.'s (1998) formulation of the SEH. Additionally, Frimmel (e.g., 2004), who has made a detailed study of the Namibian Neoproterozoic basins, questioned the heavy reliance placed on chemostratigraphy and specifically $\delta^{13} \mathrm{C}$ curves for interpreting and correlating Neoproterozoic glacigenic beds, and cited the susceptibility of carbon isotopes to syndepositional environmental conditions. His conclusions thus support those of Lindsay and Brasier (e.g., 2004) discussed above in section 3.5, and his reservations would apply 
equally to the Palaeoproterozoic carbon isotope trends (e.g., Fig. 4). Etienne et al. (2008) also questioned the relationship between glacial events and excursions of the $\delta^{13} \mathrm{C}$ curves.

The strength of arguments such as those outlined above, has led to a revised version of the SEH, the "slushball Earth hypothesis" (see also, Fairchild and Kennedy, 2007), wherein glaciation was less severe and less pervasive, thereby acceding to many of the arguments detailed by opponents of the SEH (e.g., Micheels and Montenari, 2008, for a recent example). Recently, Condie et al. (2009b) have proposed that global-scale mantle thermal inactivity and the related possibility of plate tectonic quiescence at c. 2.45-2.2 Ga may have been responsible for the first global glaciation and a first snowball Earth event at that time. Finally, it should also be considered that glaciation across a supercontinent which occupies a latitudinal position favourable for large scale glaciation (i.e., palaeomagnetic data, however questionable, supportive of low latitude glaciation), does not necessarily equate to a truly global event, but rather to a supercontinental-sized event which is significantly smaller in scale.

\subsection{Major unconformities (erosion and weathering events)}

Nelson et al. (1999) discussed a possible period of widespread erosion related to the transition from granite-greenstone continental crustal genesis to deposition of supracrustal sedimentary packages, for both the Pilbara and Kaapvaal cratons. They suggested that this period can be broadly constrained between 3125 and $3030 \mathrm{Ma}$. Yet, available precise zircon age data point to this craton-wide erosion having taken place prior to about $3070 \mathrm{Ma}$ on Kaapvaal, but after c. $3030 \mathrm{Ma}$ on Pilbara. If the potential wide ranging event is only correlatable at time scales of the order of $100 \mathrm{Ma}$, little potential exists for detailed inter-cratonic correlation.

Palaeosols have many of the inherent problems of unconformities when it comes to their application to inter-cratonic correlations, as both tend to be difficult to date directly, and palaeosols are generally smaller in their scale, commonly being specific to a single basin or only a part thereof. As an example, the palaeosol above the c. 2.2 Ga Hekpoort flood basalt within the Pretoria Group, Transvaal basin (c. 2.67 - 2.05 Ga, Kaapvaal craton) cannot be directly dated, except from the underlying volcanics, which are estimated to be $2222 \pm 12 \mathrm{Ma}(\mathrm{Pb}-\mathrm{Pb}$; Cornell et al., 1996); this is obviously only a maximum age for the palaeosol event. Even this relatively widespread and thick palaeosol (e.g., Button, 1973; Engelbrecht, 1986) is only known from one of three broadly correlated Transvaal Supergroup basins in southern Africa.

Another example of a Precambrian palaeosol is that at the base of the Kolhan Group, which overlies the c. 3.44-3.09 Ga Singhbhum craton gneissic-granitic basement rocks unconformably (Mishra et al., 1999; Misra, 2006). The Kolhan Group occurs in two separate outcrops, west of the Singhbhum granitic massif, with that in the north comprising basal immature conglomerates and sandstones ascribed to ephemeral fluvial deposition, followed by a thicker lacustrine shale succession (Bandopadhyay and Sengupta, 2004). The southern occurrence of the Kolhan has patchy occurrences of a pyrophyllite-bearing palaeosol, succeeded by lenticular braided stream granular sandstones and minor conglomerates, followed by sheet-like beach facies and uppermost wave-dominated shallow shelf deposits, as indicated by ongoing studies of the fifth author. Saha (1994) estimates the northern Kolhan sediments to be pre-2.0 Ga in age, but 
the age of the southern palaeosol can only be constrained as $<$ c. $3328 \mathrm{Ma}$ (based on age data provided by Mishra et al., 1999).

\subsubsection{Commentary}

Despite certain possible broad temporal correlations, unconformities and degradational events (e.g., as discussed for the c. 3125-3030 Ma period for the Kaapvaal and Pilbara cratons above) seem to have little potential for global correlation amongst Precambrian cratons. Such a broadly constrained erosive period as the noted example may also reflect a major change in continental freeboard conditions (cf. Eriksson et al., 2006) as crust generation was succeeded by widespread supracrustal deposition; such an "event" may be traceable across dispersed fragments of an earlier Precambrian supercontinent, but can also reflect global-scale changes and events rather than those specific to a particular cratonic amalgamation (e.g., Eriksson et al., 1999).

Establishing ages, or age ranges, for weathering events and the hiatuses implicit in unconformities remains problematic, especially for ancient Precambrian examples bearing in mind the resolution of geochronological techniques (c. 1-10 Ma at best; Catuneanu and Eriksson, 1999). Unconformities commonly reflect geological controls affecting a single basin and its surroundings, and mostly have a genesis encompassing eustasy and a broad concept of tectonism, with the latter including local tectonics, the supercontinent cycle and mantle thermal influences (e.g., Eriksson et al., 2001). Eustatic events are discussed in the following section. It is highly unlikely that unconformities related to tectonism will enable correlation amongst dispersed Precambrian cratons, although very extensive mobile belt systems allied to supercontinent assembly may possess a certain crude measure of temporal and tectonic similarity (see also, section 3.4 above).

Even within a single basin, correlation of well defined unconformities remains difficult. To take a well known Precambrian example of the oldest large preserved basin, the c. 3.1 -2.8 Ga Witwatersrand depository, correlations of the placer gold conglomeratic horizons from one goldfield to the next within what is quite a small (maximum dimensions, about $300 \mathrm{~km}$ by $200 \mathrm{~km}$ ) preserved basin has been hotly debated for decades (e.g., Els, 1998). An additional complication is provided by the classic precept in sequence stratigraphy, of basin-marginal unconformities passing into distal correlative conformities (Mitchum, 1977; Catuneanu, 2006).

Palaeosols have many of the same inherent problems, when attempting correlation. The maximum lateral extent of the southern Kolhan palaeosol is c. $45-50 \mathrm{~km}$, but its occurrence along strike is patchy and this likely reflects erosion by succeeding facies. Whether the basal ephemeral fluvial facies in the estimated $>$ c. 2.0 Ga northern Kolhan sedimentary succession may have removed an older, analogous palaeosol lying on the c. 3.3 Ga Singhbhum granitic basement is unknown. As with the Hekpoort pedogenic horizon, a palaeosol such as the Kolhan example does not offer a likely candidate for inter-craton correlation. However, as a caveat to this generalisation, it should be noted that there is a well developed palaeosol overlying the Aravalli craton basement (stabilised by c. $3.09 \mathrm{Ga}$; Misra, 2006) and another, pyrophyllite-bearing palaeosol on the basement rocks (c. 3.3-2.9 Ga; Mazumder et al., 2000 and references therein) of the Bundelkhand craton (Sharma, 1979; Roy and Paliwal, 1981; Roy et al., 1993; Pandit et al., 2008). Although it may be speculated upon that the southern Kolhan palaeosol (Singhbhum 
craton) as well as those from the Aravalli and Bundelkhand cratonic blocks may reflect a correlatable weathering event affecting Archaean basement, this cannot be proven. Additional factors which would complicate the evaluation of such a postulate would include the inferred almagamtion of the two North Indian cratonic blocks (AravalliBundelkhand) with southern cratons including Singhbhum at about 2.5 Ga (Mazumder et al., 2000) as well as the aggressive weathering generally accepted for the Archaean time period (e.g., Corcoran and Mueller, 2004). The latter factor would tend to result in rapid weathering of exposed granitic crust and lessen the likelihood of identifiable widespread distinct "events" in such ongoing processes.

\section{Discussion}

\subsection{A fallible framework of Precambrian "events"?; the case for precise chronological data}

The preceding sections provide, either individually or in their totality only a very approximate framework of "events" affecting the Precambrian history of the Earth, with no real indication of precisely dateable events which were either widespread enough around the globe or both easily identifiable and prominent enough in the rock record to materially assist in correlating amongst the relatively small and highly dispersed ancient cratons on the planet today. Perhaps the only exception to this rather negative generalisation is given by the spherule beds, but their number is very small, they are known only from two cratons, Kaapvaal and Pilbara, and their original dispersion is uncertain - i.e. their global scale is open to at least some question. What overall framework does emerge from the events discussed above? The case for supercontinentality beginning already in the Neoarchaean is relatively compelling, at least for the Precambrian supracrustal record of the cratons making up present-day North America, and for the Baltic and Siberian shields; however, the process was not affecting all cratons by any means, and it would appear that the supercontinent cycle was not yet a globally dominant or global-scale paradigm. Yet, by about $2.0 \mathrm{Ga}$, the supercontinent cycle would appear to have become fully established on Earth.

Mantle plumes are known already from the Archaean, with major superplume events at c. $2.7 \mathrm{Ga}$ and $1.9 \mathrm{Ga}$ (e.g., Condie, 2004a) bracketing the period from the first evidence for a supercontinent (Neoarchaean) to the global establishment of this cycle. With the earliest known large basin (Witwatersrand on Kaapvaal, c. 3.1-2.8 Ga), a foreland depository lasting for c. $300 \mathrm{Ma}$ (e.g., Frimmel, 2005), and protracted breakup of the first supercontinent, Kenorland, between c. 2.45 and 2.1 Ga (Aspler and Chiarenzelli, 1998), the interaction of plate tectonic and mantle thermal processes inherent in the supercontinental cycle would appear to have been slower, or at least more variable than for the Phanerozoic (cf. Catuneanu, 2001).

Major orogenic belts, as well as significant chemostratigraphic "events" such as the possible "Great Oxidation Event" at some period between about 2.3 and 2.0 Ga, the peak in and period over which the IF were deposited globally, as well as the Palaeoproterozoic and Neoproterozoic glacial epochs can all be tied to this same first-order control of plate tectonic and mantle thermal processes (e.g., Lindsay and Brasier, 2004; Young, 2004; Trendall and Blockley, 2004; Condie et al., 2009b). The time scale inherent in this first- 
order framework is of several hundred million years for major plate reorganisations and up to c. $100 \mathrm{Ma}$ for superplume events; this temporal scale is not appropriate for intercratonic correlation as striven for in this special issue. The much more precise spherule beds stand in stark contrast to this, but offer no greater advantage over and are themselves totally dependent on, precise geochronology.

As outlined earlier (section 2), most precise isotopic dating methods determine the time of formation of a mineral, such as biotite, monazite or zircon, that has a parent/daughter element ratio suitable for geochronology. Whilst most dating techniques can provide absolute age constraints on the timing of mineral formation during either igneous or metamorphic mineral (re-)crystallization events, the dating of chemostratigraphic, sedimentary deposition or glaciation "events"- events which are commonly not accompanied by formation of minerals suitable for geochronology - is difficult or impossible. In such circumstances, the best approach is to obtain easily intrepretable (igneous or metamorphic) dates for events that occurred immediately prior to and following the event of interest. However, where ash beds occur within a sedimentary succession and contain datable zircon crystals, the sedimentary rocks themselves can be accurately placed within a very accurate chronological framework. An example has been given by Altermann and Nelson (1998) who dated several such tuff beds within clastic and chemical successions in the Neoarchaean stratigraphy of the Kaapvaal craton, and were able to use these data to constrain basin history, eustatic changes (cf. events) and sedimentation rates.

\subsection{The case for sequence stratigraphy}

In addition to precise geochronology, and in contrast to most of the event-types discussed in this paper, sequence stratigraphy offers a possibly viable means of correlating cratons and their supracrustal history. It is the prime purpose of this special issue to investigate this possibility, for a chosen set of Precambrian cratons. Of all the events detailed so far, those of sequence stratigraphic affinity have the greatest potential to offer truly global-scale events. Theoretically, any eustatic change in sea level should occur right around the planet's oceans, no matter what the actual size of the change in sea level might have been; they are thus truly global in their compass. However, local to regional scale differences in the relationship between sediment supply and accommodation will greatly complicate this simple conceptual idea. Furthermore, the evidence for eustatic changes within the rock record, encompassed in the paradigm of sequence stratigraphy, is now a well established science (e.g., Catuneanu, 2006). It is for this reason that this special issue focuses on making a first-pass attempt to examine global correlations for the Precambrian time period for a set of Precambrian cratons from across the globe, based on very detailed chronostratigraphic charts (summarizing the geological evolution of each craton) and accommodation curves (for sedimentary basinfill successions), with the aim of establishing first-order and second-order sequence stratigraphy for the chosen set of cratons. 


\subsection{Eustatic events}

Eustasy refers to global changes in sea level relative to the centre of the Earth. Global eustasy is an allogenic (external) control on sedimentation which contributes to the formation of stratigraphic cycles and sequences in the rock record. In turn, eustasy depends on other allogenic controls that may cause changes in the volume of oceans, including climate change, plate-tectonic processes, mantle-thermal processes, and longer term changes in the atmosphere-hydrosphere system. Most of what we know today about the patterns of eustatic change is derived from the study of the Phanerozoic record and period.

Stratigraphic and isotopic studies revealed that eustatic fluctuations during the Phanerozoic were typically within a range of less than $350 \mathrm{~m}$, from lowstand to highstand (e.g., Haq et al., 1987, 1988; Harland et al., 1990; Miller et al., 1998, 2004). No such quantified reconstructions of eustatic curves are yet available for the Precambrian, but it is reasonable to assume that changes in accommodation of greater magnitude (i.e., $10^{3} \mathrm{~m}$ ) in any particular basin were likely controlled by mechanisms other than eustasy, involving regional (rather than global) tectonism and mantle-thermal processes. Exceptions from this uniformitarian inference may be explained by long-term chemical changes in the atmosphere-hydrosphere system, which may have caused much greater fluctuations in the volume of oceans in the Precambrian relative to what is known for the Phanerozoic.

The global nature of sea-level fluctuations renders eustasy as a mechanism that may enable and also explain global correlations (Vail et al., 1977; Haq et al., 1987), assuming that adequate time-control validates the correlations (Miall, 1992, 1994). The global signature of eustasy may be obscured in the rock record by interference with the effects of tectonic and mantle-thermal controls that may operate independently at smaller, continental and sub-continental scales. As a result, changes in accommodation often have local rather than global significance (Catuneanu, 2006).

Fluctuations in global sea level may occur over a wide range of temporal scales, depending on the dominant driving mechanism. High-frequency eustatic fluctuations are commonly attributed to global climate changes controlled by orbital forcing (i.e., Milankovitch cycles) with periodicities of $10^{4}-10^{5}$ years (Imbrie and Imbrie, 1979). Increasingly longer term eustatic cycles may be related to plate kinematics and the associated volume changes in mid-oceanic spreading centres $\left(10^{6}-10^{8}\right.$ year time scales) (Vail et al., 1977; Eriksson et al., 1999; Miall, 2000). Such fluctuations in the intensity of mid-oceanic actvitiy generate eustatic cycles of different magnitudes and temporal wavelengths in the course of the formation and breakup of supercontinents. Additional controls on eustatic fluctuations, which appear to have been more important during the Precambrian, include superplume events and changes in the atmosphere-hydrosphere system (Eriksson et al., 2004b).

The correlation between the duration of stratigraphic cycles and their causal mechanisms can only be tentative, because different and independent controls may compete in terms of generating cycles of similar durations. For example, high-frequency stratigraphic sequences of $10^{4}-10^{5}$ years duration may be generated both by climatedriven eustasy and by tectonic processes such as periodic brittle failure of the crust in convergent plate-margin settings or periodic adjustments to the flexural load in foreland 
systems (Peper et al., 1992; Waschbusch and Royden, 1992; Miall, 2000). Lower frequency eustatic cycles induced by changes in the volume of mid-oceanic spreading centres $\left(10^{6}-10^{8}\right.$ years periodicity) also compete in terms of duration with cycles generated by extensional downwarp and loading of the crust or by continental-scale mantle-thermal processes (i.e., dynamic topography; Mitrovica et al., 1989; Gurnis, 1992; Holt and Stern, 1994; Catuneanu et al., 1997; Miall, 2000).

The intricate interplay between the various allogenic controls on stratigraphic cyclicity makes it difficult to quantify their relative contribution to the preserved stratigraphic record. Care must therefore be taken when interpreting the origin of stratigraphic cycles, especially for studies that focus only on continental to sub-continental scales. In this context, global correlation becomes an important test of eustasy, within the limits imposed by the precision and accuracy of the available age-dating techniques. Given the error margin of radiochronology (normally c. $10 \mathrm{Ma}$; section 2), the correlation of larger scale (higher rank/order) cycles around the world is a realistic starting point for testing the effects of eustasy on the Precambrian stratigraphic record.

\section{Conclusions}

This paper attempts to set up a first-pass framework of chronological "events" which provide a practical means to attempt correlation between currently widely dispersed Precambrian cratons on Earth. The discussions above, particularly in sections 3 and 4 of this paper, suggest that almost all of the events detailed (cf., supercontinent-, mantle plume-, orogenic-, chemostratigraphic-, glacial events and major unconformities), can be related essentially to the large scale interaction of plate tectonic and mantle thermal (plume) processes, with the likely exception of impact events and their associated spherule beds. These large scale tectonic-thermal processes are, in any case, inferred to be responsible for and compatible in length with first- and second-order sequence stratigraphic or eustatic cycles, which may offer a means for correlation across Precambrian cratonic terranes. It is precisely for this reason, thus, that this special issue focuses on producing accommodation curves at these cyclical temporal scales for a number of the well known and studied Precambrian cratons of the world.

\section{Acknowledgements}

PGE acknowledges research funding from the National research Foundation, South Africa and the University of Pretoria, and thanks Mrs. M. Geringer and Mrs. T. Rajab for their drafting skills. The authors appreciate the improvements to the manuscript brought about by reviews from Kent Condie and Chris Fedo, as well as editorial input from Adam Bumby. 


\section{References}

Abbott, D.H., Hagstrum, J.T., 2004. Strategies for finding the record of early Precambrian impact events. In: Eriksson, P.G., Altermann, W., Nelson, D.R., Mueller, W.U., Catuneanu, O. (Eds.), The Precambrian Earth: tempos and events. Elsevier, Amsterdam, pp. 45-62.

Abbott, D.H., Isley, A., 2002. Extraterrestrial Influences on Mantle Plume Activity. Earth and Planetary Science Letters 205, 53-62.

Altermann, W., Nelson, D.R., 1998. Sedimentation rates, basin analysis and regional correlations of three Neoarchaean and Palaeoproterozoic sub-basins of the Kaapvaal craton as inferred from precise $\mathrm{U}-\mathrm{Pb}$ zircon ages from volcaniclastic sediments. Sedimentary Geology 120, 225-256.

Aspler, L.B., Chiarenzelli, J.R., 1998. Two Neoarchean supercontinents? Evidence from the Paleoproterozoic. Sedimentary Geology 120, 75-104.

Bandopadhyay, P.C., Sengupta, S., 2004. The Paleoproterozoic supracrustal Kolhan Group in Singhbhum Craton, India and the Indo-African supercontinent. Gondwana Research 7(4), 1228-1235.

Bjerrum, C.J., Canfield, D.E., 2002. Ocean productivity before about 1.9 Gyr ago limited by phosphorus adsorption onto iron oxides. Nature 417, 159-162.

Blackwelder, E., 1926. Precambrian geology of the Medicine Bow Mountains. Geological Society of America Bulletin 37, 615-658.

Bleeker, W., 2003. The late Archean record: A puzzle in ca. 35 pieces. Lithos 71(2-4), 99-134.

Bleeker, W., Ernst, R.E., 2006. Short-lived mantle generated magmatic events and their dyke swarms: The key unlocking Earth's paleogeographic record back to $2.6 \mathrm{Ga}$. In: Hanski, E., Mertanen, S., Rämö, T., Vuollo, J. (Eds.), Dyke Swarms - Time Markers of Crustal Evolution. A.A. Balkema, Rotterdam, pp. 3-26.

Boshoff, R., Van Reenen, D.D., Kramers, J.D., Smit, C.A., Perchuk, L.L., Armstrong, R., 2006. Geologic history of the Central Zone of the Limpopo Complex: The West Alldays area. Journal of Geology 114, 699-716.

Bumby, A.J., Van der Merwe, R., 2004. The Limpopo Belt of Southern Africa: a Neoarchaean to Palaeoproterozoic orogen. In: Eriksson, P.G., Altermann, W., Nelson, D.R., Mueller, W.U., Catuneanu, O. (Eds.), The Precambrian Earth: tempos and events. Elsevier, Amsterdam, pp. 217-223. 
Bumby, A.J., Eriksson, P.G., van der Merwe, R., Brümmer, J.J., 2001. Shear-zone controlled basins in the Blouberg area, Northern Province, South Africa: syn- and posttectonic sedimentation relating to c. $2.0 \mathrm{Ga}$ reactivation of the Limpopo Belt. Journal of African Earth Sciences 33, 445-461.

Button, A., 1973. A regional study of the stratigraphy and development of the Transvaal Basin in eastern and northeastern Transvaal. Ph.D. thesis (unpubl.), University of the Witswatersrand, Johannesburg, 352p.

Button, A., 1976. Transvaal and Hamersley basins - review of basin development and mineral deposits. Minerals Science and Engineering 8, 262-292.

Catuneanu, O., 2001. Flexural partitioning of the Late Archaean Witwatersrand foreland system, South Africa. Sedimentary Geology 141-142, 95-112.

Catuneanu, O., 2006. Principles of Sequence Stratigraphy. Elsevier, Amsterdam, 375 pp.

Catuneanu, O., Eriksson, P.G., 1999. The sequence stratigraphic concept and the Precambrian rock record: an example from the 2.7-2.1 Ga Transvaal Supergroup, Kaapvaal craton. Precambrian Research 97, 215-251.

Catuneanu, O., Beaumont, C., Waschbusch, P., 1997. Interplay of static loads and subduction dynamics in foreland basins: Reciprocal stratigraphies and the "missing" peripheral bulge. Geology 25 (12), 1087-1090.

Catuneanu, C., Martins-Neto, M.A., Eriksson, P.G., 2005. Precambrian sequence stratigraphy. Sedimentary Geology 176, 67-95.

Cheney, E.S., 1996. Sequence stratigraphy and plate tectonic significance of the Transvaal succession of southern Africa and its equivalent in Western Australia. Precambrian Research 79, 3-24.

Cloud, P.E., 1968. Atmospheric and hydrospheric evolution on the primitive earth. Science 160, 729-736.

Coleman, A.P., 1926. Ice Ages, Recent and Ancient. Macmillan, New York, 296p.

Compston, W., Jeffery, P.M., 1959. Anomalous 'common strontium' in granite. Nature, 1792-1793.

Condie, K.C. (Ed.), 1992. Proterozoic Crustal Evolution. Elsevier, Amsterdam, 510p.

Condie, K.C., 1998. Episodic continental growth and supercontinents: a mantle avalanche connection? Earth and Planetary Science Letters 163, 97-108. 
Condie, K. C., 2001. Mantle Plumes and their Record in Earth History. Cambridge University Press, Cambridge, 305p.

Condie, K.C., 2004a. Precambrian superplume events. In: Eriksson, P.G., Altermann, W., Nelson, D.R., Mueller, W.U., Catuneanu, O. (Eds.), The Precambrian Earth: tempos and events. Elsevier, Amsterdam, pp. 163-173.

Condie, K.C., 2004b. Supercontinents and superplume events: distinguishing signals in the geological record. Physics of the Earth and Planetary Interiors 146, 319-332.

Condie, K. C., Des Marais, D. J., Abbott, D., 2001. Precambrian superplumes and supercontinents: a record in black shales, carbon isotopes, and paleoclimates? Precambrian Research 106(3-4), 239-260.

Condie, K.C., Belousova, E., Griffin, W.L., Sircombe, K.N., 2009a. Granitoid events in space and time: Constraints from igneous and detrital zircon age spectra. Gondwana Research 15, 228-242.

Condie, C.K., O'Neill, C., Aster, R., 2009b. Evidence and implications for a widespread magmatic shutdown for 250 My on Earth. Earth and Planetary Science Letters 282, 294298.

Corcoran, P.L., Mueller, W.U., 2004. Aggressive Archaean weathering. In: Eriksson, P.G., Altermann, W., Nelson, D.R., Mueller, W.U., Catuneanu, O. (Eds.), The Precambrian Earth: tempos and events. Elsevier, Amsterdam, pp. 494-504.

Cornell, D.H., Schütte, S.S., Eglington, B.L., 1996. The Ongeluk Basaltic Andesite Formation in Griqualand West, South Africa: submarine alteration in a $2222 \mathrm{Ma}$ Proterozoic sea. Precambrian Research 79, 101-124.

Dalziel, I.W.D., 1997. Overview: Neoproterozoic-Palaeozoic geography and tectonics: review, hypothesis, environmental speculations. Geological Society of America Bulletin $109,16-42$.

De Wit, M.J., 1998. On Archean granites, greenstones, cratons and tectonics: does the evidence demand a verdict? Precambrian Research 91, 181-226.

Dimroth, E., Kimberley, M.M., 1976. Precambrian atmospheric oxygen: evidence in the sedimentary distributions of carbon, sulfur, uranium, and iron. Canadian Journal of Earth Sciences 13, 1161-1185.

Els, B.G., 1998. The auriferous Late Archaean sedimentation systems of South Africa: unique palaeoenvironmental conditions? Sedimentary Geology 120, 205-224. 
Embleton, B. J. J., Williams, G. E., 1986. Low palaeolatitudes of deposition for late Precambrian periglacial varvites in South Australia: implications for palaeoclimatology. Earth and Planetary Science Letters 79, 419-430.

Engelbrecht, J.P., 1986. Die Bosveldkompleks en sy vloergesteentes in die omgewing van Nietverdiend, Wes-Transvaal. PhD thesis (unpublished), University of Pretoria, South Africa, 327p.

England, P.C., Thompson, A., 1984. Pressure-temperature-time paths of regional metamorphism. I. Heat transfer during the evolution of regions of thickened continental crust. Journal of Petrology 25, 894-928.

Eriksson, P.G., Altermann, W., 2004a. Introduction, Chapter 5: Evolution of the hydrosphere and atmosphere. In: Eriksson, P.G., Altermann, W., Nelson, D.R., Mueller, W.U., Catuneanu, O. (Eds.), The Precambrian Earth: Tempos and Events. Elsevier, Amsterdam, pp. 359-361.

Eriksson, P.G., Altermann, W., 2004b. Commentary, Chapter 5: Evolution of the hydrosphere and atmosphere. In: Eriksson, P.G., Altermann, W., Nelson, D.R., Mueller, W.U., Catuneanu, O. (Eds.), The Precambrian Earth: Tempos and Events. Elsevier, Amsterdam, pp. 505-511.

Eriksson, P.G., Catuneanu, O., 2004. A commentary on Precambrian plate tectonics. In: Eriksson, P.G., Altermann, W., Nelson, D.R., Mueller, W.U., Catuneanu, O. (Eds.), The Precambrian Earth: Tempos and Events. Elsevier, Amsterdam, pp. 201-213.

Eriksson, P.G., Condie, K.C., Tirsgaard, H., Mueller, W.U., Altermann, W., Miall, A.D., Aspler, L.B., Catuneanu, O., Chiarenzelli, J.R., 1998. Precambrian clastic sedimentation systems. Sedimentary Geology 120, 5-53.

Eriksson, P.G., Mazumder, R., Sarkar, S., Bose, P.K., Altermann, W., van der Merwe, R., 1999. The 2.7-2.0 Ga volcano-sedimentary record of Africa, India and Australia: evidence for global and local changes in sea level and continental freeboard. Precambrian Research 97, 269-302.

Eriksson, P.G., Martins-Neto, M.A., Nelson, D.R., Aspler, L.B., Chiarenzelli, J.R., Catuneanu, O., Sarkar, S., Altermann, W., Rautenbach, C.J.deW., 2001. An introduction to Precambrian basins: their characteristics and genesis. Sedimentary Geology 141-142, $1-35$.

Eriksson, P.G., Catuneanu, O., Nelson, D.R., Mueller, W.U., Altermann, W., 2004a. Towards a synthesis. In: Eriksson, P.G., Altermann, W., Nelson, D.R., Mueller, W.U., Catuneanu, O. (Eds.), The Precambrian Earth: tempos and events. Elsevier, Amsterdam, pp. 739-769. 
Eriksson, P.G., Altermann, W., Nelson, D., Mueller, W.U., Catuneanu, O. (Eds.), 2004b. The Precambrian Earth: Tempos and Events. Elsevier, Amsterdam, 941p.

Eriksson, P.G., Catuneanu, O., Sarkar, S., Tirsgaard, H., 2005a. Patterns of sedimentation in the Precambrian. Sedimentary Geology 176, 17-42.

Eriksson, P.G., Els, B.G., Bumby, A.J., 2005b. Kaapvaal craton: Changing first- and second-order controls on sea level from c. $3 \mathrm{Ga}$ to $2.0 \mathrm{Ga}$. Sedimentary Geology 176, 121-148.

Eriksson, P.G., Mazumder, R., Catuneanu, O., Bumby, A.J., Ountsché Ilondo, B., 2006. Precambrian continental freeboard and geological evolution: A time perspective. EarthScience Reviews 79, 165-204.

Eriksson, P.G., Banerjee, S., Catuneanu, O., Sarkar, S., Bumby, A.J., Mtimkulu, M.N., 2007. Prime controls on Archaean-Palaeoproterozoic sedimentation: Change over time. Gondwana Research 12, 550-559.

Eriksson, P.G., Banerjee, S., Nelson, D.R., Rigby, M.J., Catuneanu, O., Sarkar, S., Roberts, R.J., Ruban, D., Mtimkulu, M.N., Sunder Raju, P.V., 2009a. A Kaapvaal craton debate: Nucleus of an early small supercontinent or affected by an enhanced accretion event? Gondwana Research 15, 354-372.

Eriksson, P.G., Rautenbach, C.J.deW., Wright, D.T., Bumby, A.J., Catuneanu, O., Mostert, P., van der Neut, M., 2009b. Possible evidence for episodic epeiric marine and fluvial sedimentation (and implications for palaeoclimatic conditions), c. 2.3-1.8 Ga, Kaapvaal craton, South Africa. Palaeogeography, Palaeoclimatology, Palaeoecology 273, 153-173.

Ernst, R. E., Buchan, K. L., 2002. Maximum size and distribution in time and space of mantle plumes: evidence from large igneous provinces. Journal of Geodynamics 34, 309342.

Ernst, R.E., Buchan, K.L., Prokoph, A., 2004. Large igneous province record through time. In: Eriksson, P.G., Altermann, W., Nelson, D.R., Mueller, W.U., Catuneanu, O. (Eds.), The Precambrian Earth: tempos and events. Elsevier, Amsterdam, pp. 173-180.

Ernst, R.E., Buchan, K.L., Campbell, I.H., 2005. Frontiers in Large Igneous Province research. Lithos 79, 271-297.

Etienne, J.L., Allen, P.A., Rieu, R., Le Guerroué, E., 2008. Neoproterozoic glaciated basins: a critical review of the Snowball Earth hypothesis by comparison with Phanerozoic glaciations. Nature Geoscience 1, 817-825.

Evans, D.A., Beukes, N.J., Kirschvink, J.L., 1997. Low latitude glaciation in the Palaeoproterozoic era. Nature 386, 262-266. 
Fairchild, I.J., Kennedy, M.J., 2007. Neoproterozoic glaciation in the Earth System. Journal of the Geological Society, London 164, 895-921.

Frimmel, H.E., 2004. Neoproterozoic sedimentation rates and timing of glaciations - a southern African perspective. In: Eriksson, P.G., Altermann, W., Nelson, D.R., Mueller, W.U., Catuneanu, O. (Eds.), The Precambrian Earth: tempos and events. Elsevier, Amsterdam, pp. 459-472.

Frimmel, H.E., 2005. Archaean atmospheric evolution: evidence from the Witwatersrand gold fields, South Africa. Earth-Science Reviews 70, 1-46.

Gaál, G., 1992. Global Proterozoic tectonic cycles and Early Proterozoic metallogeny. South African Journal of Geology 95, 79-87.

Gerdes, A., Zeh, A., 2009. Zircon formation versus zircon alteration - New insights from combined $\mathrm{U}-\mathrm{Pb}$ and Lu-Hf in-situ LA-ICP-MS analyses, and consequences for the interpretation of Archean zircon from the Central Zone of the Limpopo Belt. Chemical Geology 261, 230-243.

Glikson, A.Y., 2001. The astronomical connection of terrestrial evolution: crustal effects of post-3.8 Ga mega-impact clusters and evidence for major 3.2 $\pm 0.1 \mathrm{Ga}$ bombardment of the Earth-Moon system. Journal of Geodynamics 32, 205-229.

Glikson, A., 2006. Asteroid impact ejecta units overlain by iron-rich sediments in 3.5-2.4 Ga terrains, Pilbara and Kaapvaal cratons: Accidental or cause-effect relationships? Earth and Planetary Science Letters 246, 149-160.

Glikson, A.Y., 2008. Field evidence of Eros-scale asteroids and impact-forcing of Precambrian geodynamic episodes, Kaapvaal (South Africa) and Pilbara (Western Australia) Cratons. Earth and Planetary Science Letters 267, 558-570.

Glikson, A., Vickers, J., 2007. Asteroid mega-impacts and Precambrian banded iron formations: 2.63 and $2.56 \mathrm{Ga}$ impact ejecta/fallout at the base of BIF/argillite units, Hamersley Basin, Pilbara Craton, Western Australia. Earth and Planetary Science Letters 254, 214-226.

Gray, D.R., Foster, D.A., Meert, J.G., Goscombe, B.D., Armstrong, R., Truow, R.A.J., Passchier, C.W., 2008. A Damaran orogen perspective on the assembly of southwestern Gondwana. Special Publication, Geological Society, London 294, 257-278.

Grieve, R.A.F., 1998. Extraterrestrial impacts on earth: The evidence and the consequences. In: Grady, M.M., Hutchison, R., McCall, G.J.H., Rothery, D.A. (Eds.), Meteorites: Flux with Time and Impact Effects. Special Publication, Geological Society, London 140, pp. 105-131. 
Gurnis, M. 1988. Large-scale mantle convection and the aggregation and dispersal of supercontinents. Nature 332, 695-699.

Gurnis, M., 1992. Rapid continental subsidence following the initiation and evolution of subduction. Science 255, 1556-1558.

Gurnis, M., Torsvik, T.H., 1994. Rapid drift of large continents during the late Precambrian and Palaeozoic: Palaeomagnetic constraints and dynamic models. Geology 22, 1023-1026.

Hambrey, M. J., Harland, W.B. (Eds.), 1981. Earth's pre-Pleistocene glacial record. Cambridge University Press, Cambridge, 1004 p.

Haq, B.U., Hardenbol, J., Vail, P.R., 1987. Chronology of fluctuating sea levels since the Triassic (250 million years ago to present). Science 235, 1156-1166.

Haq, B.U., Hardenbol, J., Vail, P.R., 1988. Mesozoic and Cenozoic chronostratigraphy and cycles of sea-level change. In: Wilgus, C.K., Hastings, B.S., Kendall, C.G.St.C., Posamentier, H.W., Ross, C.A., Van Wagoner, J.C. (Eds.), Sea Level Changes - An Integrated Approach. Special Publication, Society of Economic Paleontologists and Mineralogists, Tulsa, Oklahoma 42, pp. 71-108.

Harland, W. B., 1964. Critical evidence for a great Infra-Cambrian glaciation. Geologische Rundschau 54, 45-61.

Harland, W. B., Bidgood, D. E. T., 1959. Paleomagnetism in some Norwegian sparagmites and the late-Precambrian ice age. Nature 184, 1860-1862.

Harland, W.B., Armstrong, R.L., Cox, A.V., Craig, L.E., Smith, A.G., Smith, D.G., 1990. A geologic time scale, 1989. Cambridge University Press, Cambridge, 263p.

Hartz, E.H., Torsvik, T.H., 2002. Baltica upside-down: a new plate-tectonic model for Rodinia and the Iapetus Ocean. Geology 30, 255-258.

Hassler, S.W., Simonson, B.M., 2001. The sedimentary record of extraterrestrial impacts in deep shelf environments - Evidence from the early Precambrian. Journal of Geology $109,1-22$.

Hassler, S.W., Simonson, B.M., Sumner, D.Y., Murphy, D., 2005. The sedimentary record of extraterrestrial impacts in deep shelf environments: evidence from the early Precambrian. Australian Journal of Earth Sciences 52, 759-772.

Hoffman, P.F., 1988. United plates of America, the birth of a craton: Early Proterozoic assembly and growth of Laurentia. Annual Reviews of Earth and Planetary Science 16, 543-603. 
Hoffman, P. F., Kaufman, A. J., Halverson, G. P., Schrag, D. P., 1998. A Neoproterozoic Snowball Earth. Science 281, 1342-1346.

Holland, H.D., 1973. The oceans: a possible source of iron in iron-formations. Economic Geology 68, 1169-1172.

Holland, H.D., 1978. The Chemistry of the Atmosphere and Oceans. Princeton University Press, Princeton, New Jersey, 351p.

Holland, H.D., 1984. The Chemical Evolution of the Atmosphere and the Oceans. Princeton University Press, Princeton, New Jersey, 582p.

Holland, H.D., 2002. Volcanic gases, black smokers, and the great oxidation event. Geochimica et Cosmochimica Acta 66, 3811-3826.

Holmund, P., Näslund, J.-E., 1994. The glacially sculptured landscape in Dronning Maud Land, Antarctica, formed by wet-based mountain glaciation and not by the present ice sheet. Boreas 23, 139-148.

Holt, W.E., Stern, T.A., 1994. Subduction, platform subsidence and foreland thrust loading: The late Tertiary development of Taranaki basin, New Zealand. Tectonics 13, 1068-1092.

Holzer, L., Kamber, B., Kramers, J.D., Frei, R., 1996. The tectonometamorphic event at 2 Ga in the Limpopo Belt and the resetting behaviour of chronometers at high temperature. Special Publication, Geological Survey of Namibia 1, 127-138.

Holzer, L., Frei, R., Barton, J.M., Kramers, J.D., 1998. Unraveling the record of successive high grade events in the Central Zone of the Limpopo Belt using $\mathrm{Pb}$ single phase dating of metamorphic minerals. Precambrian Research 87, 87-115.

Honda, S., Yoshida, M., Ootorii, S., Iwase, Y., 2000. The timescales of plume generation caused by continental aggregation. Earth and Planetary Science Letters 176, 31-43.

Imbrie, J., Imbrie, K.P., 1979. Ice ages: solving the mystery. Enslow, Hillside, New Jersey, 224p.

Isley, A.E., Abbott, D.H., 1999. Plume-related mafic volcanism and the deposition of banded iron formation. Journal of Geophysical Research B 104, 15461-15477.

Kamber, B.S., Blenkinsop, T.G., Villa, I.M., Dahl, P.S., 1995. Proterozoic transpressive deformation in the Northern Marginal Zone, Limpopo Belt, Zimbabwe. Journal of Geology 100, 490-508.

Kasting, J.F., Siefert, J.L., 2002. Life and the evolution of Earth's atmosphere. Science 296, 1066-1068. 
Kirschvink, J. L., 1992. Late Proterozoic low-latitude global glaciation: The snowball Earth. In: Schopf, J.W., Klein, C. (Eds.), The Proterozoic Biosphere: a multidisciplinary study. Cambridge University Press, Cambridge, pp. 51-52.

Klein, C., Beukes, N.J., 1989. Geochemistry and sedimentology of a facies transition from limestone to iron-formation deposition in the early Proterozoic Transvaal Supergroup, South Africa. Economic Geology 84, 1733-1774.

Kleman, J., 1994. Preservation of landforms under ice sheets and ice caps. Geomorphology 9, 19-32.

Koeberl, C., 1992. Tektite origin by hypervelocity asteroidal or cometary impact; the quest for the source craters. Lunar and Planetary Institute Contribution 790, 42 - 43.

Koeberl, C., Reimold, W.U., 1995. Early Archaean spherule beds in the Barberton Mountain Land, South Africa: no evidence for impact origin. Precambrian Research 74, $1-33$.

Kröner, A., Jaeckel, P., Brandl, G., Nemchin, A.A., Pidgeon, R.T., 1999. Single zircon ages for granitoid gneisses in the Central Zone of the Limpopo Belt, Southern Africa and geodynamic significance. Precambrian Research 93, 299-337.

Larson, R. L., 1991. Latest pulse of Earth: evidence for a mid-Cretaceous superplume. Geology 19, 547-550.

Lasaga, A.C., Ohmoto, H., 2002. The oxygen geochemical cycle: dynamics and stability. Geochimica et Cosmochimica Acta 66, 361-381.

Li, Z.-X., Zhang, L., Powell, C.M., 1995. South China in Rodinia: Part of the missing link between Australia-East Antarctica and Laurentia? Geology 23, 407-410.

Li, Z.-X., Zhang, L., Powell, C.M., 1996. Positions of the east Asian cratons in the Neoproterozoic supercontinent Rodinia. Australian Journal of Earth Sciences 43, 593604.

Lindsay, J.F., Brasier, M.D., 2004. The evolution of the Precambrian atmosphere: carbon isotopic evidence from the Australian continent. In: Eriksson, P.G., Altermann, W., Nelson, D.R., Mueller, W.U., Catuneanu, O. (Eds.), The Precambrian Earth: tempos and events. Elsevier, Amsterdam, pp. 388-403.

Lowe, D.R., Byerly, G.R., Kyte, F.T., Shukolyukov, A., Asaro, F., Krull, A., 2003. Spherule beds 3.47-3.24 billion years old in the Barberton Greenstone Belt, South Africa: A record of large meteorite impacts and their influence on early crustal and biological evolution. Astrobiology 3, 7-48. 
Mahan, K.H., Goncalves, P., Flowers, R., Williams, M.L., Hoffman-Setka, D., 2008. The role of heterogeneous strain in the development and preservation of a polymetamorphic record in high- $P$ granulites, western Canadian Shield. Journal of Metamorphic Geology 26, 669-694.

Manning, S., 1999. Test of time: The volcano of Thera and the chronology and history of the Aegean and east Mediterranean in the mid second millennium BC. Oxbow, Oxford, $494 \mathrm{p}$.

Marmo, J. S., Ojakangas, R. W., 1984. Proterozoic glaciogenic deposits, eastern Finland. Bulletin of the Geological Society of America 95, 1055-1062.

Martin, D. M., 1999. Depositional setting and implications of Paleoproterozoic glaciomarine sedimentation in the Hamersley Province, Western Australia. Bulletin of the Geological Society of America 111, 189-203.

Mazumder, R., Bose, P.K., Sarkar, S., 2000. A commentary on the tectono-sedimentary record of the pre-2.0 Ga continental growth of India vis-à-vis a possible pre-Gondwana Afro-Indian supercontinent. Journal of African Earth Sciences 30, 201-217.

McCourt, S., Armstrong, R.A., 1998. SHRIMP U-Pb zircon geochronology of granites from the Central Zone, Limpopo Belt, southern Africa: implications for the age of the Limpopo Orogeny. South African Journal of Geology 101, 329-338.

McCourt, S., Vearncombe, J.R., 1992. Shear zones of the Limpopo Belt and adjacent granitoid-greenstone terranes, implications for late Archaean collision tectonics in Southern Africa. Precambrian Research 55, 553-570.

Meert, J.G., 2002. Paleomagnetic evidence for a Paleo-Mesoproterozoic supercontinent. Gondwana Research 5, 207-215.

Meert, J.G., 2003. A synopsis of events related to the assembly of the eastern Gondwana. Tectonophysics 362(1-4), 1-40.

Meert, J.G., Tamrat, E., 2004. A mechanism for explaining rapid continental motion in the late Neoproterozoic. In: Eriksson, P.G., Altermann, W., Nelson, D.R., Mueller, W.U. Catuneanu, O. (Eds.), The Precambrian Earth: tempos and events. Elsevier, Amsterdam, pp. 255-267.

Meert, J.G., Torsvik, T.H., 2003. The making and unmaking of a supercontinent: Rodinia revisited. Tectonophysics 375(1-4), 261-288.

Meert, J.G., Lieberman, B.S., 2008. The Neoproterozoic assembly of Gondwana and its relationship to the Ediacaran-Cambrian radiation. Gondwana Research 14, 5-21.

Menzies, J. 1995. Modern Glacial Environments. Butterworth Heinemann, Oxford, 621p. 
Miall, A.D., 1992. Exxon global cycle chart: an event for every occasion? Geology 20, 787-790.

Miall, A. D., 1994. Sequence stratigraphy and chronostratigraphy: problems of definition and precision in correlation, and their implications for global eustasy. Geoscience Canada 21, 1-26.

Miall, A.D., 2000. Principles of Sedimentary Basin Analysis $3^{\text {rd }}$ edition. Springer, Berlin, $616 \mathrm{p}$.

Micheels, A., Montenari, M., 2008. A snowball Earth versus a slushball Earth: Results from Neoproterozoic climate modelling sensitivity experiments. Geosphere 4, 401-410.

Miller, K.G., Mountain, G.S., Browning, J.V., Kominz, M.A., Sugarman, P.J., ChristieBlick, N., Katz, M.E., Wright, J.D., 1998. Cenozoic global sea-level, sequences, and the New Jersey transect: results from coastal plain and slope drilling. Reviews of Geophysics $36,569-601$.

Miller, K.G., Sugarman, P.J., Browning, J.V., Kominz, M.A., Olsson, R.K., Feigenson, M.D., Hernandez, J.C., 2004. Upper Cretaceous sequences and sea-level history, New Jersey Coastal Plain. Bulletin of the Geological Society of America 116(3/4), 368-393.

Millonig, L., Zeh, A., Gerdes, A., Klemd, R., 2008. Late Archaean high-grade metamorphism in the Central Zone of the Limpopo Belt (South Africa): Petrological and geochronological evidence from the Bulai Pluton. Lithos 103, 333-351.

Mishra, S., Deomurari, M.P., Wiedenbeck, M., Goswami, J.N., Ray, S., Saha, A.K., 1999. ${ }^{207} \mathrm{~Pb} /{ }^{206} \mathrm{~Pb}$ zircon ages and the evolution of the Singhbhum Craton, eastern India: an ion microprobe study. Precambrian Research 93, 139-151.

Misra, S., 2006. Precambrian chronostratigraphic growth of Singhbhum-Orissa Craton, Eastern Indian Shield: An alternative model. Journal Geological Society of India 67, 356378.

Mitchum, R.M. Jr., 1977. Seismic stratigraphy and global changes of sea level, part 11: glossary of terms used in seismic stratigraphy. In: Payton, C.E. (Ed.), Seismic Stratigraphy - Applications to Hydrocarbon Exploration. American Association of Petroleum Geologists Memoir 26, pp. 205-212.

Mitrovica, J.X., Beaumont, C., Jarvis, G.T., 1989. Tilting of continental interiors by the dynamical effects of subduction. Tectonics 8, 1079-1094.

Nelson, D.R., 2008. Geochronology of the Archean of Australia. Australian Journal of Earth Sciences 55, 1-15. 
Nelson, D.R., Trendall, A.F., Altermann, W., 1999. Chronological correlations between the Pilbara and Kaapvaal cratons. Precambrian Research 97, 165-189.

Nesbitt, H.W., Young, G.M., 1982. Early Proterozoic climates and plate motions inferred from major element chemistry of lutites. Nature 299, 715-717.

Ohmoto, H., 2004. The Archaean atmosphere, hydrosphere and biosphere. In: Eriksson, P.G., Altermann, W., Nelson, D.R., Mueller, W.U., Catuneanu, O. (Eds.), The Precambrian Earth: tempos and events. Elsevier, Amsterdam, pp. 361-388.

Ojakangas, R.W., 1988. Glaciation: An uncommon 'mega-event' as a key to intracontinental and intercontinental correlation of Early Proterozoic basin fill, North American and Baltic cratons. In: Kleinspehn, K., Paola, C. (Eds.), New Perspectives in Basin Analysis. Springer, New York, pp. 431-444.

Ouzegane, K., Kienast, J.-R., Bendaoud, A., Drareni, A., 2003. A review of Archaean and Paleoproterozoic evolution of the In Ouzzal granulitic terrane (Western Hoggar, Algeria). Journal of African Earth Sciences 37, 207-227.

Page, N.J., 1981. The Precambrian diamictite below the base of the Stillwater Complex, Montana. In: Hambrey, M.J., Harland, W.B. (Eds.), Earth's Pre-Pleistocene glacial record. Cambridge University Press, Cambridge, pp. 821-823.

Pandit, M.K., de Wall, H., Chauhan, N.K., 2008. Paleosol at the Archean-Proterozoic contact in NW India revisited: Evidence for oxidizing conditions during paleoweathering? Journal of Earth System Science 117, 201-209.

Peper, T., Beekman, F., Cloetingh, S., 1992. Consequences of thrusting and intraplate stress fluctuations for vertical motions in foreland basins and peripheral areas. Geophysical Journal International 111, 104-126.

Perchuk, L.L., Van Reenen, D.D., Varlamov, D.A., van Kal, S.M., Tabatabeimanesh, Boshoff, R., 2008. P-T record of two high-grade metamorphic events in the Central Zone of the Limpopo Complex, South Africa. Lithos 103, 70-105.

Pesonen, L.J., Elming, S.-A., Mertanen, S., Pisarevsky, S., D'Agrella-Filho, M.S., Meert, J.G., Schmidt, P.W., Abrahamsen, N., Bylund, G., 2003. Palaeomagnetic configuration of continents during the Proterozoic. Tectonophysics 375, 289-324.

Piper, J.D.A., 1976. Palaeomagnetic evidence for a Proterozoic supercontinent. Philosophical Transactions of the Royal Society of London A280, 469-490.

Piper, J.D.A., 1983. Proterozoic palaeomagnetism and single continent plate tectonics. Geophysical Journal of the Royal Astronomical Society 74, 163-197. 
Powell, R., Holland, T.J.B., 2008. On thermobarometry. Journal of Metamorphic Geology 26, 155-179.

Rasmussen, B., Koeberl, C., 2004. Iridium anomalies and shocked quartz in a late Archean spherule layer from the Pilbara Craton: new evidence for a major asteroid impact at $2.63 \mathrm{Ga}$. Geology 32, 1029-1032.

Rasmussen, B., Blake, T.S., Fletcher, I.R., 2005. U-Pb zircon age constraints on the Hamersley spherule beds: evidence for a single 2.63 Ga Jeerinah-Carawine impact ejecta layer. Geology 33, 725-728.

Rigby, M.J., 2009. Conflicting $P-T$ paths within the Central Zone of the Limpopo Belt: A consequence of different thermobarometric methods? Geological Society of Africa Presidential Review \# 13. Journal of African Earth Sciences, in press.

Rigby, M.J., Mouri, H., Brandl, G. 2008a. A review of the P-T-t evolution of the Limpopo Belt: constraints for a tectonic model. Journal of African Earth Sciences 50, 120-132.

Rigby, M.J., Brandl, G., Mouri, H. 2008b. P-T conditions and the origin of quartzofeldspathic veins in metasyenites from the Central Zone of the Limpopo Belt, South Africa. South African Journal of Geology 111, 313-332.

Roering, C., van Reenen, D.D., Smit, C.A., Barton, J.M., de Beer, J.H., De Wit, M.J., Stettler, E.H., van Schalkwyk, J.F., Stevens, G., Pretorius, S., 1992. Tectonic model for the evolution of the Limpopo Belt. Precambrian Research 55, 539-552.

Rogers, J.J.W., 1996. A history of continents in the past three billion years. Journal of Geology 104, 91-107.

Rogers, J.J.W., Santosh, M., 2002. Configuration of Columbia, a Mesoproterozoic supercontinent. Gondwana Research 5, 5-22.

Rogers, J.J.W., Santosh, M., 2009. Tectonics and surface effects of the supercontinent Columbia. Gondwana Research 15, 373-380.

Roy, A.B., Paliwal, B.S., 1981. Evolution of Lower Proterozoic epicontinental deposits: stromatolite-bearing Aravalli rocks of Udaipur, Rajasthan, India. Precambrian Research $14,49-74$.

Roy, A.B., Sharma, B.L., Paliwal, B.S., Chauhan, N.K., Nagori, D.K., Golani, P.R., Bejarniya, B.R., Bhu, H., Ali, S.M., 1993. Lithostratigraphy and tectonic evolution of the Aravalli Supergroup - A protogeosynclinal sequence. In: Casshyap, S.M. (Ed.), Rifted Basins and Aulacogens. Ganodaya Prakashan, Nainital, India, pp. 73-88. 
Ruban, D.A., 2007. Amalgamation and destruction of Baltica during the ProterozoicPhanerozoic: a comparative analysis of the continent evolution. In: Glebovitskij, V.A. (Ed.), Aktual'nye problemy geologii dokembrija, geofiziki i geoekologii. SanktPeterburg, IGiGD, pp. 23-25 (in Russian).

Rye, R., Holland, H.D., 2000. Life associated with a 2.76 Ga ephemeral pond? Evidence from Mount Roe \#2 paleosol. Geology 28, 483-486.

Saha, A.K., 1994. Crustal evolution of Singhbhum north Orissa. Eastern India. Memoir, Geological Society of India 27, 341p.

Santosh, M., Maruyama, S., Yamamoto, S., 2009. The making and breaking of supercontinents: Some speculations based on superplumes, super downwelling and the role of tectosphere. Gondwana Research 15, 324-341.

Schaller, M., Steiner, O., Studer, I., Holzer, L., Herwegh, M., Kramers, J., 1999. Exhumation of Limpopo Central Zone granulites and dextral continent-scale transcurrent movement at $2.0 \mathrm{Ga}$ along the Palala Shear Zone, Northern Province, South Africa. Precambrian Research 96, 263-288.

Schmidt, P.W., Williams, G.E., 1995. The Neoproterozoic climatic paradox: Equatorial palaeolatitude for Marinoan glaciation near sea level in South Australia. Earth and Planetary Science Letters 134, 107-124.

Schmidt, P.W., Williams, G.E., Embleton, B.J.J., 1991. Low palaeolatitude of Late Proterozoic glaciation: early timing of remanence in haematite of the Elatina Formation, South Australia. Earth and Planetary Science Letters 105, 355-367.

Sharma, R.P., 1979. Origin of the pyrophyllite-diaspore deposits of the Bundelkhand complex, central India. Mineralium Deposita 14, 343-352.

Sheldon, N.D., 2006. Precambrian paleosols and atmospheric $\mathrm{CO}_{2}$ levels. Precambrian Research 147, 148-155.

Simonson, B.M., 1992. Geological evidence for a strewn field of impact spherules in the early Precambrian Hamersley Basin of Western Australia. Geological Society of America Bulletin 104, 829-839.

Simonson, B.M., Glass, B.P., 2004. Spherule layers - records of ancient impacts. Annual Review of Earth and Planetary Science 32, 329-361.

Simonson, B.M., Byerly, G.R., Lowe, D.R., 2004. The early Precambrian stratigraphic record of large extraterrestrial impacts. In: Eriksson, P.G., Altermann, W., Nelson, D.R., Mueller, W.U., Catuneanu, O. (Eds.), The Precambrian Earth: tempos and events. Elsevier, Amsterdam, pp. 27-45. 
Smit, J., 1999. The global stratigraphy of the Cretaceous-Tertiary boundary impact ejecta. Annual Review of Earth and Planetary Science 27, 75-113.

Sohl, L. E., Christie-Blick, N., Kent, D. V., 1999. Paleomagnetic polarity reversals in Marinoan (ca. $600 \mathrm{Ma}$ ) glacial deposits of Australia: Implications for the duration of lowlatitude glaciation in Neoproterozoic time. Geological Society of America Bulletin 111, 1120-1139.

Squire, R.J., Campbell, I.H., Allen, C.M., Wilson, C.J.L., 2006. Did the Transgondwanan Supermountain trigger the explosive radiation of animals on Earth? Earth and Planetary Science Letters 250/1-2, 116-133.

Stanistreet, I.G., 1993. Ancient and modern examples of tectonic escape basins: the Archaean Witwatersrand Basin compared with the Cenozoic Maracaibo Basin. In: Frostick, L.E., Steel, R.J. (Eds.), Tectonic Controls and Signatures in Sedimentary Successions. Special Publication, International Association of Sedimentologists 20, Blackwell, Oxford, pp. 363-376.

Stern, R.J., 1994. Arc assembly and continental collision in the Neoproterozoic East African Orogen: implications for the consolidation of Gondwanaland. Annual Review of Earth and Planetary Sciences 22, 319-351.

Strand, K.O., Laajoki, K., 1993. Paleoproterozoic glaciomarine sedimentation in an extensional setting: the Honkala Formation, Finland. Precambrian Research 64, 253-271.

Tohver, E., D’Agrella-Filho, M.S., Trindade, R.I.F., 2006. Paleomagnetic record of Africa and South America for the 1200-500 Ma interval, and evaluation of Rodinia and Gondwana assemblies. Precambrian Research 147, 193-222.

Trendall, A. F., 1981. The Lower Proterozoic Meteorite Bore Member, Hamersley Basin, Western Australia. In: Hambrey, M.J., Harland, W.B. (Eds.), Earth's pre-Pleistocene glacial record. Cambridge University Press, Cambridge, pp. 555-557.

Trendall, A.F., 2002. The significance of iron-formation in the Precambrian stratigraphic record. In: Altermann, W., Corcoran, P.L. (Eds.), Precambrian Sedimentary Environments: a Modern Approach to Depositional Systems. Special Publication, International Association of Sedimentologists 44, Blackwell, pp. 33-66.

Trendall, A.F., Blockley, J.G., 1970. The iron formations of the Precambrian Hamersley Group, Western Australia, with special reference to the associated crocidolite. Bulletin, Western Australia Geological Survey 119, 365p.

Trendall, A.F., Blockley, J.G., 2004. Precambrian iron-formation. In: Eriksson, P.G., Altermann, W., Nelson, D.R., Mueller, W.U., Catuneanu, O. (Eds.), The Precambrian Earth: tempos and events. Elsevier, Amsterdam, pp. 403-421. 
Unrug, R., 1992. Supercontinent cycle and Gondwana assembly: component cratons and timing of suturing events. Journal of Geodynamics 12, 703-714.

Vail, P.R., Mitchum, R.M. Jr., Thompson, S., III, 1977. Seismic stratigraphy and global changes of sea level, part four: global cycles of relative changes of sea level. American Association of Petroleum Geologists Memoir 26, 83-98.

Van Reenen, D.D., Barton, J.M., Roering, C., Smit, C.A., Van Schalkwyk, J.F., 1987. Deep crustal response to continental collision: The Limpopo Belt of southern Africa. Geology 15, 11-14.

Van Reenen, D.D., Boshoff, R., Smit, C.A., Perchuk, L.L., Kramers, J.D., McCourt, S., Armstrong, R.A., 2008. Geochronological problems related to polymetamorphism in the Limpopo Complex, South Africa. Gondwana Research 14, 644-662.

Vaughan, A.P.M., Pankhurst, R.J., 2008. Tectonic overview of the West Gondwana margin. Gondwana Research 13/2, 150-162.

Visser, J. N. J., 1981. The Mid-Precambrian tillite in the Griqualand West and Transvaal Basins, South Africa. In: Hambrey, M.J., Harland, W.B. (Eds.), Earth's Pre-Pleistocene Glacial Record. Cambridge University Press, Cambridge, pp. 180-184.

Von Brunn, V., Gold, D. J. D., 1993. Diamictite in the Archean Pongola sequence of southern Africa. Journal of African Earth Sciences 16, 367-374.

Walker, J.C.G., 1977. Evolution of the Atmosphere. Macmillian, New York, 318p.

Waschbusch, P.J., Royden, L.H., 1992. Episodicity in foredeep basins. Geology 20, 915918.

Weil, A.B., Van Der Voo, R., Mac Niocaill, C., Meert, J.G., 1998. The Proterozoic supercontinent Rodinia: Paleomagnetically derived reconstructions for 1100 to $800 \mathrm{Ma}$. Earth and Planetary Science Letters 154, 13-24.

Williams, G. E., 1975. Late Precambrian glacial climate and the Earth's obliquity. Geological Magazine 112, 441-465.

Williams, G. E., 1986. Precambrian permafrost horizons as indicators of palaeoclimate. Precambrian Research 32, 233-242.

Williams, G.E., 1998. Precambrian tidal and glacial clastic deposits: implications for Precambrian Earth-Moon dynamics and palaeoclimate. Sedimentary Geology 120, 5574.

Williams, G.E., 2004. The paradox of Proterozoic glaciomarine deposition, open seas and strong seasonality near the Palaeo-Equator: global implications. In: Eriksson, P.G., 
Altermann, W., Nelson, D.R., Mueller, W.U., Catuneanu, O. (Eds.), The Precambrian Earth: tempos and events. Elsevier, Amsterdam, pp. 448-459.

Williams, G.E., 2008. Proterozoic (pre-Ediacaran) glaciation and the high obliquity, lowlatitude ice, strong seasonality (HOLIST) hypothesis: Principles and tests. Earth Science Reviews 87, 61-93.

Williams, G. E., Schmidt, P. W., 1997. Paleomagnetism of the Paleoproterozoic Gowganda and Lorrain Formations, Ontario: low paleolatitude for Huronian glaciation. Earth and Planetary Science Letters 153, 157-169.

Williams, G.E., Gostin, V.A., McKirdy, D.M., Preiss, W.V., 2008. The Elatina glaciation, late Cryogenian (Marinoan Epoch), South Australia: Sedimentary facies and palaeoenvironments. Precambrian Research 163, 307-331.

Williams, H., Hoffman, P.F., Lewry, J.F., Monger, J.W.H., Rivers, T., 1991. Anatomy of North America: thematic portrayals of the continent. Tectonophysics 187, 117-134.

Wingate, M.T.D., 1998. A palaeomagnetic test of the Kaapvaal-Pilbara (Vaalbara) connection at $2.78 \mathrm{Ga}$. South African Journal of Geology 101, 257-274.

Young, G. M., 1970. An extensive early Proterozoic glaciation in North America? Palaeogeography, Palaeoclimatology and Palaeoecology 7, 85-101.

Young, G. M., 1973. Tillites and aluminous quartzites as possible time markers for Middle Precambrian (Aphebian) rocks of North America. In: Young, G.M. (Ed.), Huronian stratigraphy and sedimentation. Geological Association of Canada, pp. 97-127.

Young, G. M., 1992. Neoproterozoic glaciation in the Broken Hill area, New South Wales, Australia. Geological Society of America Bulletin 104, 840-850.

Young, G.M., 1995. Are Neoproterozoic glacial deposits preserved on the margins of Laurentia related to the fragmentation of two supercontinents? Geology 23, 153-156.

Young, G.M., 2004. Earth's two great Precambrian glaciations: aftermath of the "Snowball Earth" hypothesis. In: Eriksson, P.G., Altermann, W., Nelson, D.R., Mueller, W.U., Catuneanu, O. (Eds.), The Precambrian Earth: tempos and events. Elsevier, Amsterdam, pp. 440-448.

Zeh, A., Klemd, R., Buhlmann, S., Barton, J.M., 2004. Pro- and retrograde P-T evolution of granulites of the Beit Bridge Complex (Limpopo Belt, South Africa): Constraints from quantitative phase diagrams and geotectonic implications. Journal of Metamorphic Geology 22, 79-95.

Zeh, A., Holland, T.J.B., Klemd, R., 2005. Phase relationships in grunerite-garnetbearing amphibolites in the system CFMASH, with applications to metamorphic rocks 
from the Central Zone of the Limpopo Belt, South Africa. Journal of Metamorphic Geology 23, 1-16.

Zeh, A., Gerdes, A., Klemd, R., Barton Jr., J.M., 2007. Archaean to Proterozoic crustal evolution in the central zone of the Limpopo Belt (South Africa-Botswana): Constraints from combined $\mathrm{U}-\mathrm{Pb}$ and $\mathrm{Lu}-\mathrm{Hf}$ isotope analyses of zircon. Journal of Petrology 48, 1605-1639.

Zhong, S., Zhang, N., Li, Z.-X., Roberts. J.H., 2007. Supercontinent cycles, true polar wander, and very long-wave length mantle convection. Earth and Planetary Science Letters 261, 551-564. 
Figure 1. Schematic summary time chart of Earth evolution from c. $4.4-1.6 \mathrm{Ga}$, showing inferred major changes and events as well as their possible impact on the sedimentary record (modified after Eriksson et al., 2007). Note possible "superevents" identified at c. $2.7 \mathrm{Ga}$ and from c. $2.2-1.8 \mathrm{Ga}$.

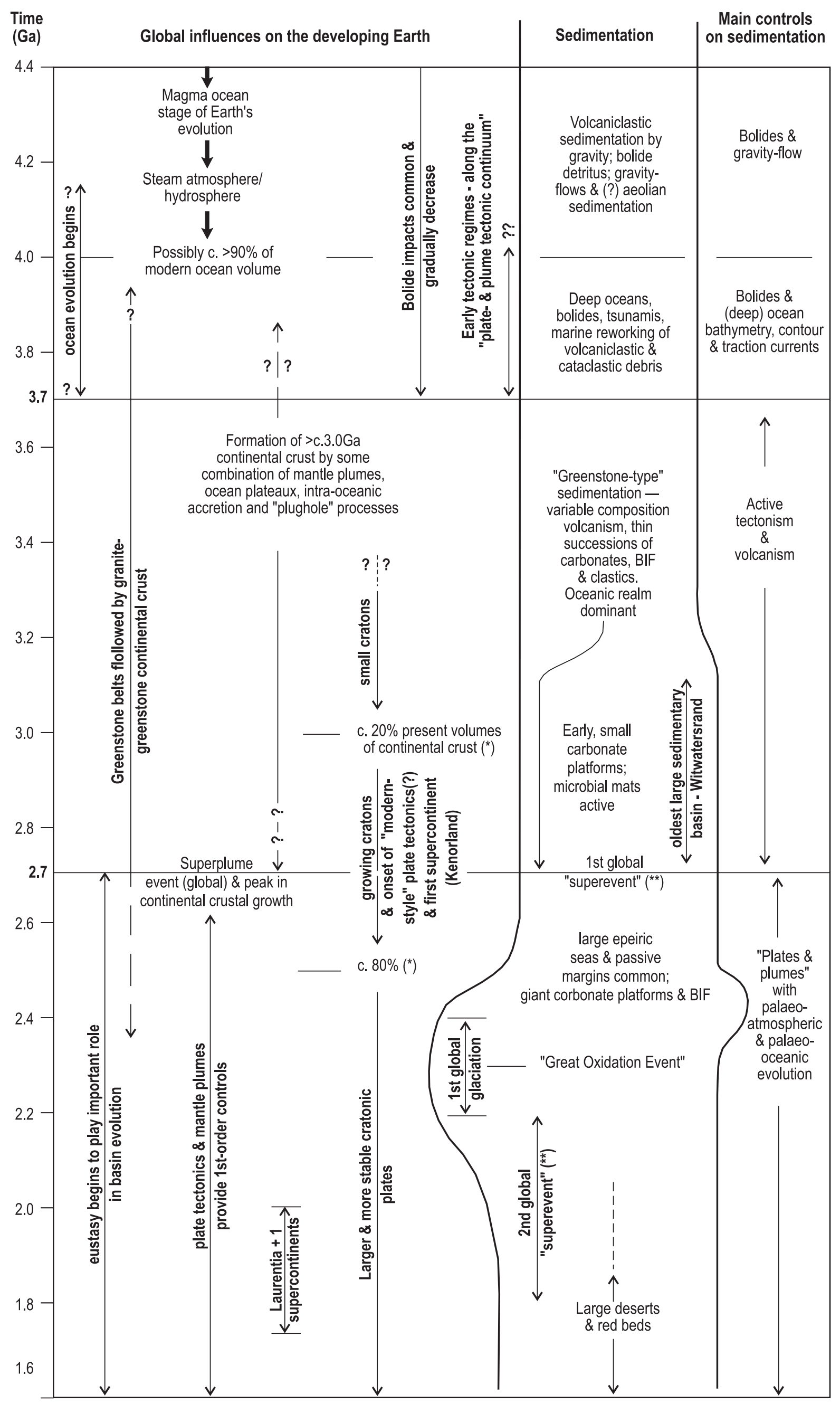




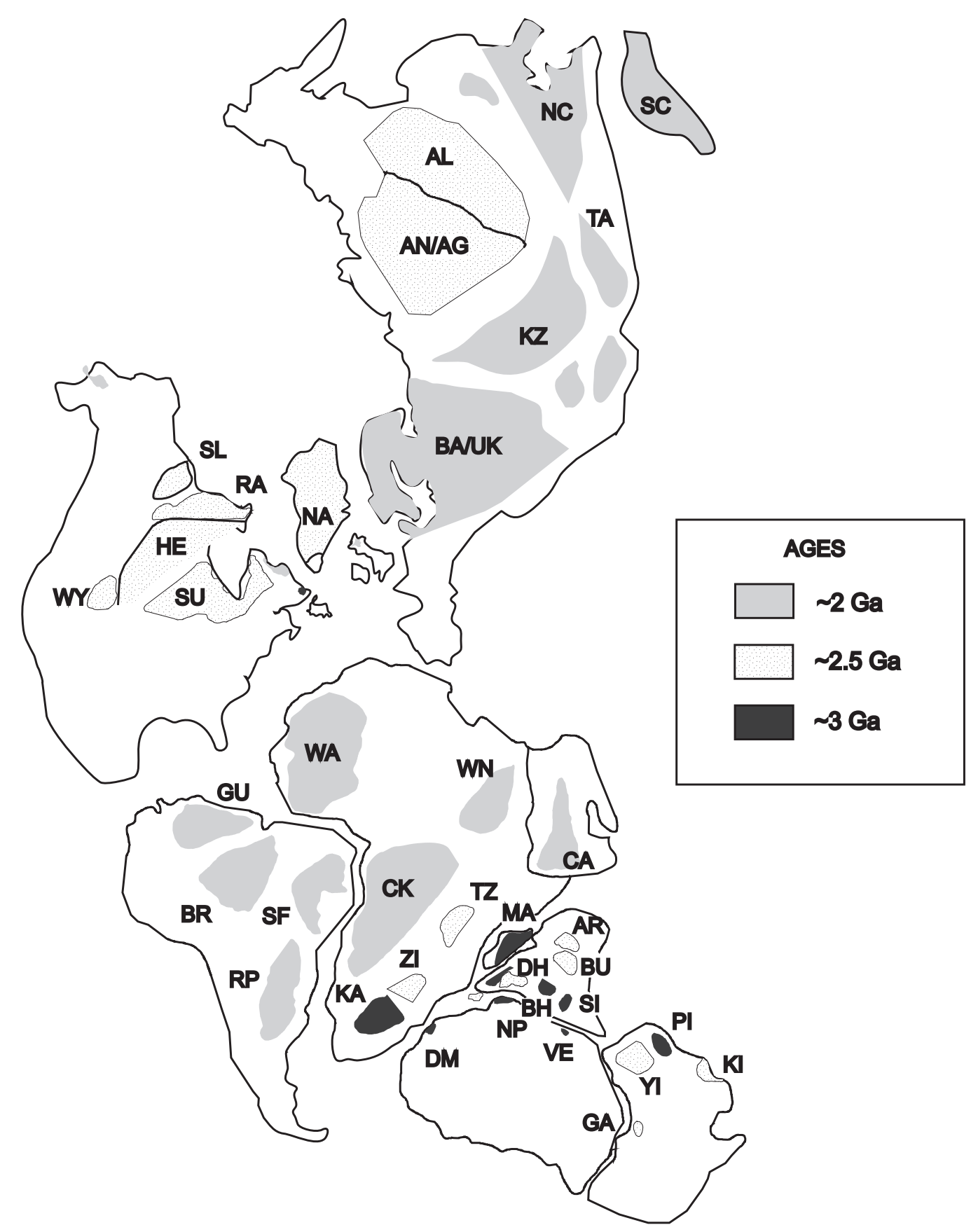

Flat map projection of supercontinent Pangea showing the modern shapes of the constituent continents, as well as the older cratons which had also formed part of earlier supercontinents such as Ur, Nena, Columbia (see section 3.1 in this paper) in their relative positions within the continents as they occur today. Letters used to denote Precambrian cratons (which are grouped into three age groups, using shadings): $A L=$ Aldan, AN/AG = Anabar/Angara, $\mathrm{AR}=$ Aravalli, $\mathrm{BA} / \mathrm{UK}=$ Baltica/Ukraine, $\mathrm{BH}=$ Bhandara (Bastar), $\mathrm{BR}=$ Brazil (Guapore), $\mathrm{BU}=$ Bundelkhand, $\mathrm{CA}=$ Central Arabia, $\mathrm{CK}=\mathrm{Congo} / \mathrm{Kasai}, \mathrm{DH}=$ Dharwar (both west and east), $\mathrm{DM}=$ western Dronning Maud Land, GA = Gawler, GU = Guiana, HE = Hearne, KA = Kaapvaal, $\mathrm{KI}=$ Kimberley, $\mathrm{KZ}=$ Kazakhstan, $\mathrm{MA}=$ Madagascar, NA = North Atlantic (includes Nain, Greenland, Lewisian), NC = North China (Sino-Korean), NP = Napier, PI = Pilbara, RA = Rae, RP = Rio de la Plata, $\mathrm{SC}=$ South China (Cathaysia and Yangtze), SF = São Francisco, $\mathrm{SI}=$ Singhbhum, $\mathrm{SL}=$ Slave, $\mathrm{SU}=$ Superior, $\mathrm{TA}=$ Tarim, $\mathrm{TZ}=$ Tanzania, $\mathrm{VE}=$ Vestfold, $\mathrm{WA}=$ West Africa (includes small São Luis craton), WN = West Nile (Nile-Uweinat), YL - Yilgarn, and ZI = Zimbabwe. Modified after Rogers and Santosh (2009). 
Figure 3. The assembled Precambrian shields and orogens of Gondwana. Note that the orogens span a large time range (from c. $940-530$ Ma) and that each major orogen encompasses a complex series of orogenic events (see section 3.4 in text for discussion). Viewed very simplistically, the main sutures related to the formation of Gondwana are (1) the Brasiliano-Damara orogen (assembly of western Gondwana), (2) the Kuungan orogen (assembly of eastern Gondwana), and (3) the East African orogen (assembly of East and West Gondwana).

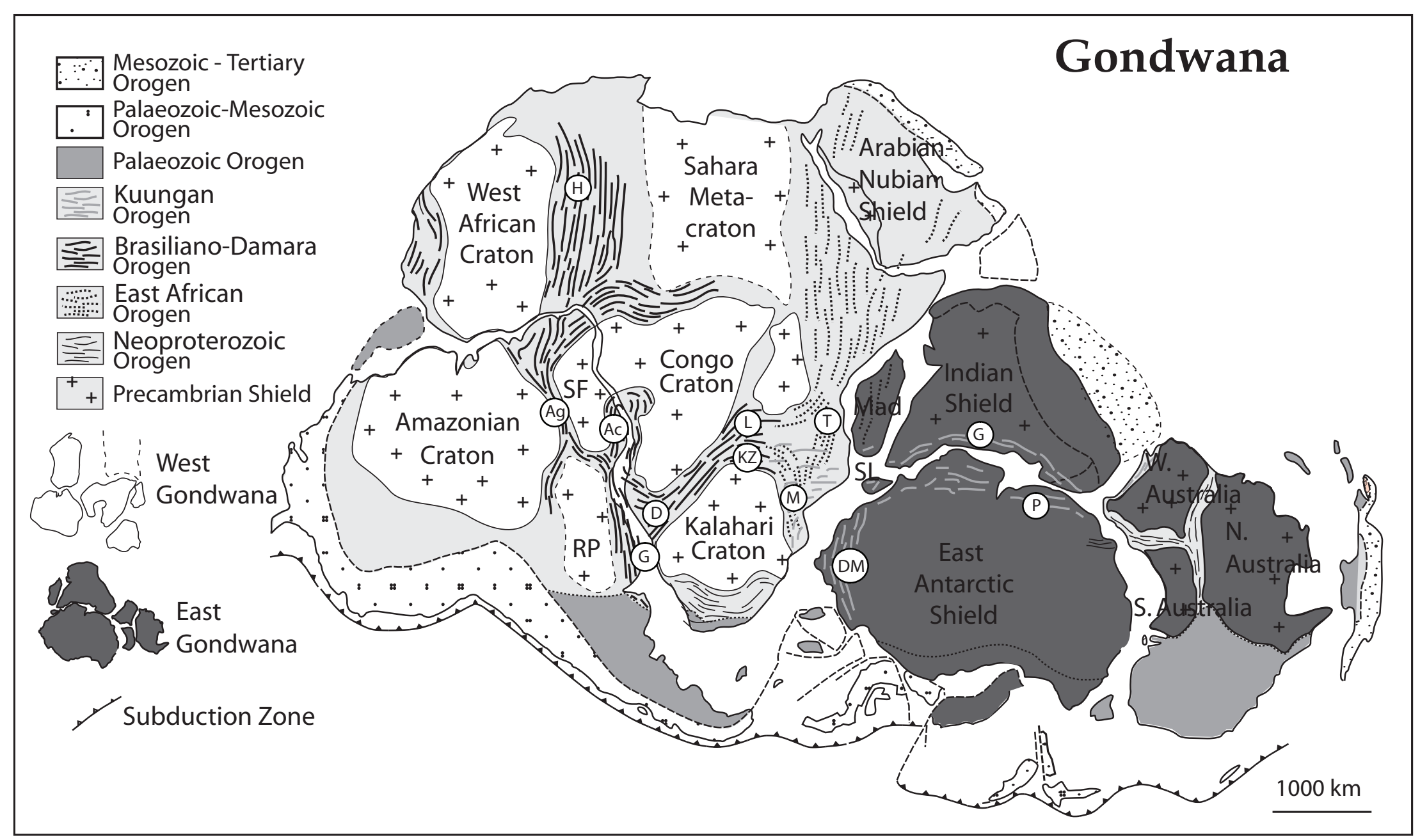




\section{TIME Ga}

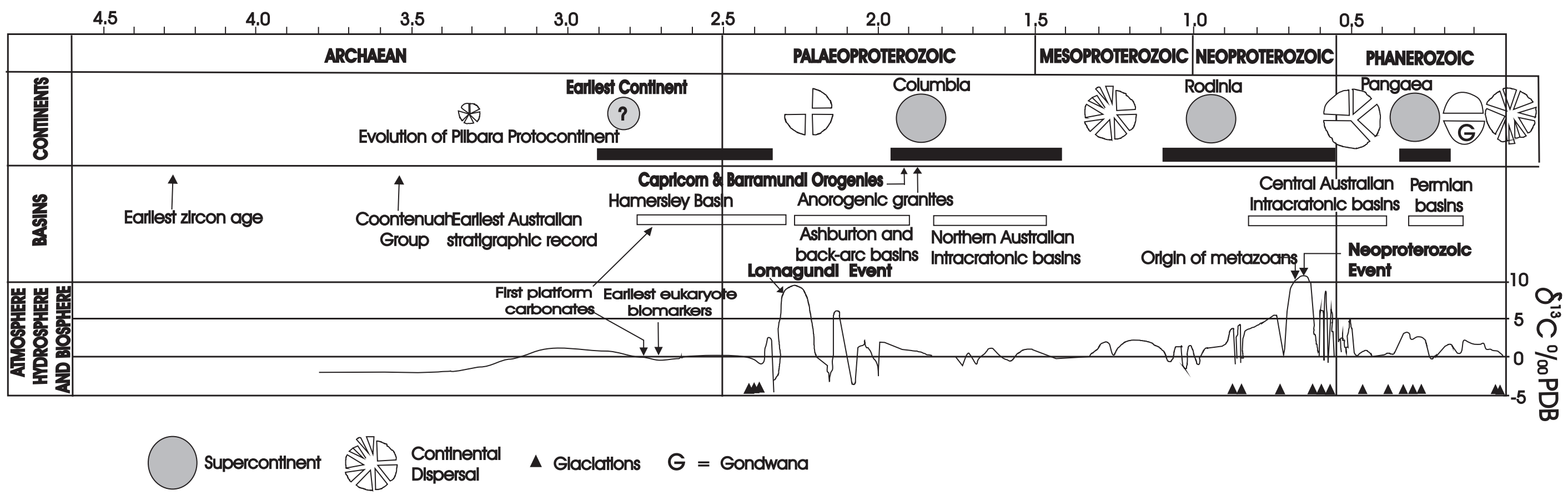

A schematic summary chart of the carbon isotope curve (a proxy for the inferred Precambrian palaeo-redox; Ohmoto, 2004) over geological time. Also shown are tectonic (particularly global supercontinent assemblies and breakups, and known intracratonic basins from Australia) and biospheric changes through time. Note two major positive (oxygen) excursions at c. $2.3 \mathrm{Ga}$ (the "Lomagundi Event" or "Great Oxidation event") and c. 0.65 Ga (the so-called "Neoproterozoic event"). Black bars = global supercontinent events; hachured bars = intracratonic basins within the Australian continent. Carbon isotopic curve is based on that given by Lindsay and Brasier (2004; see also references therein). 